\title{
Subcellular forms and biochemical events triggered in human cells by HCV polyprotein expression from a viral vector
} Andrée M Vandermeeren ${ }^{1}$, Carmen Elena Gómez ${ }^{1}$, Cristina Patiño², Elena Domingo-Gili1 , Susana Guerra ${ }^{1}$, Jose Manuel González ${ }^{1}$ and Mariano Esteban*1

Address: ${ }^{1}$ Department of Molecular and Cellular Biology, Centro Nacional de Biotecnología, CSIC, Campus Universidad Autónoma, E-28049, Madrid, Spain and 2Electron Microscopy Service, Centro Nacional de Biotecnología, CSIC, Campus Universidad Autónoma, E-28049, Madrid, Spain

Email: Andrée M Vandermeeren - avandermeeren@pharmamar.com; Carmen Elena Gómez - cegomez@cnb.csic.es; Cristina Patiño - cpatino@cnb.csic.es; Elena Domingo-Gil - edomingo@cnb.csic.es; Susana Guerra - sguerra@cnb.csic.es; Jose Manuel González - jmglez@cnb.csic.es; Mariano Esteban* - mesteban@cnb.csic.es

* Corresponding author

Published: 15 September 2008

Virology Journal 2008, 5:102 doi:10.1186/1743-422X-5-102

This article is available from: http://www.virologyj.com/content/5/I/I02

(C) 2008 Vandermeeren et al; licensee BioMed Central Ltd.

This is an Open Access article distributed under the terms of the Creative Commons Attribution License (http://creativecommons.org/licenses/by/2.0), which permits unrestricted use, distribution, and reproduction in any medium, provided the original work is properly cited.
Received: 21 July 2008

Accepted: 15 September 2008

\begin{abstract}
To identify the subcellular forms and biochemical events induced in human cells after $\mathrm{HCV}$ polyprotein expression, we have used a robust cell culture system based on vaccinia virus (VACV) that efficiently expresses in infected cells the structural and nonstructural proteins of HCV from genotype Ib (VT7-HCV7.9). As determined by confocal microscopy, HCV proteins expressed from VT7-HCV7.9 localize largely in a globular-like distribution pattern in the cytoplasm, with some proteins co-localizing with the endoplasmic reticulum (ER) and mitochondria. As examined by electron microscopy, HCV proteins induced formation of large electron-dense cytoplasmic structures derived from the ER and containing HCV proteins. In the course of HCV protein production, there is disruption of the Golgi apparatus, loss of spatial organization of the ER, appearance of some "virus-like" structures and swelling of mitochondria. Biochemical analysis demonstrate that HCV proteins bring about the activation of initiator and effector caspases followed by severe apoptosis and mitochondria dysfunction, hallmarks of HCV cell injury. Microarray analysis revealed that $\mathrm{HCV}$ polyprotein expression modulated transcription of genes associated with lipid metabolism, oxidative stress, apoptosis, and cellular proliferation. Our findings demonstrate the uniqueness of the VT7-HCV7.9 system to characterize morphological and biochemical events related to $\mathrm{HCV}$ pathogenesis.
\end{abstract}

\section{Background}

Hepatitis C virus (HCV) infection is a major cause of chronic hepatitis, liver cirrhosis and hepatocellular carcinoma [1]. With over 170 million people chronically infected with HCV worldwide, this disease has emerged as a serious global health problem.
The HCV virus is the sole member of the genus hepacivirus which belongs to the Flaviviridae family, represented by six major genotypes. The viral genome is a positive polarity single-stranded RNA molecule of approximately $9.5 \mathrm{~kb}$ in length that has a unique open-reading frame, coding for a single polyprotein. The length of the polypro- 
tein-encoding region varies according to the isolate and genotype of the virus from 3,008 to 3,037 amino acids. After virus entry and uncoating, the viral genome serves as template for the translation of the single polyprotein which is processed by cellular and viral proteases to yield the mature structural (Core-E1-E2-p7) and nonstructural proteins (NS2-NS3-NS4A-NS4B-N5A-NS5B) [2,3].

Despite the identification of $\mathrm{HCV}$ as the most common etiologic agent of posttransfusion and sporadic non-A, non-B hepatitis, its replication cycle and pathogenesis are incompletely understood. Improvement has been made using heterologous expression systems, functional fulllength cDNA clones, and subgenomic replicons [4-6]. The recent establishment of a cell culture system for $\mathrm{HCV}$ propagation is a major progress to analyse the complete viral life cycle and HCV virus-host interactions [7-9].

The impact of HCV polyprotein expression in human cells has been hampered by limitations of different cell systems to express the entire HCV polyprotein in high yields and in all cells. Vaccinia virus (VACV), a prototype member of the poxvirus family, has proven to be a useful vector for faithful expression of many proteins in cells [10,11]. We have previously described a novel poxvirus-based delivery system that is inducible and expresses the structural and nonstructural (except C-terminal part of NS5B) proteins of HCV ORF from genotype 1b [12]. In this model, we observed that HCV proteins control cellular translation through eIF-2 $\alpha$-S51 phosphorylation, with involvement of the double-stranded RNA-dependent protein kinase PKR. Moreover, in VT7-HCV7.9 infected cells HCV proteins bring about an apoptotic response through the activation of the RNase L pathway [12].

As it has been considered that the viral cytopathic effect might be involved in the liver-cell injuries $[1,2,13]$, here we have analyzed in detail the subcellular forms and biochemical changes occurring in human cells (HeLa and hepatic HepG2) following expression of the HCV polyprotein from VACV recombinant. We found that the production of HCV proteins in the host cell from 4 to $48 \mathrm{~h}$ induced severe cellular damage with modifications in cell organelles, formation of large cytoplasmic membrane structures and activation of death pathways, hallmarks of HCV cell injury. In addition, we analyzed by microarray technology the gene expression profile of HeLa cells infected with VT7-HCV7.9 recombinant and identified genes that were differentially regulated by HCV proteins and are related with HCV pathogenesis. The morphological and biochemical changes triggered in human cells by HCV polyprotein expression highlight the use of the poxvirus-based system as a suitable model in the study of the biology of HCV infection and morphogenesis, host-cell interactions and drug-treatment.

\section{Results \\ HCV proteins induced disruption of the Golgi apparatus and co-localized with ER and mitochondria markers}

We have previously described that the DNA fragment of $\mathrm{HCV}$ ORF from genotype $1 \mathrm{~b}$ included in the VT7-HCV 7.9 recombinant is efficiently transcribed and translated upon induction with IPTG into a viral polyprotein precursor that is correctly processed into mature structural and nonstructural (except the C-terminal part of NS5B) HCV proteins [12].

To identify the cytoplasmic compartment(s) in which viral HCV proteins accumulated during infection of HeLa cells with VT7-HCV ${ }_{7.9}$, we performed immunofluorescence analysis using serum from an HCV-infected patient to recognize HCV proteins and antibodies specific for the Golgi apparatus (anti-gigantin), the endoplasmic reticulum (anti-calnexin) or the mitochondria (mitotracher) (Fig. 1). Inducible expression of HCV proteins caused severe disruption of the Golgi apparatus as revealed by labelling this organelle with a specific antibody (Fig. 1A). This effect was not observed in cells infected with VT7$\mathrm{HCV}_{7.9}$ in the absence of IPTG. There is no co-localization of HVC proteins with the disrupted Golgi, whereas in the labelling of the endoplasmic reticulum, a clear co-localization between HCV proteins expressed from VT7- $\mathrm{HCV}_{7.9}$ and ER proteins was observed (Fig. 1B). With an in vivo mitochondrial marker (Fig. 1C), we detected partial colocalization between HCV proteins expressed from VT7$\mathrm{HCV}_{7 .}$ and mitochondria organelles. Moreover, the mitochondria appeared more rounded in cells infected with

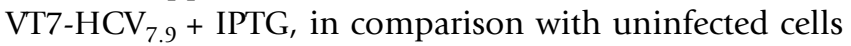
or with cells infected in the absence of IPTG.

\section{HCV polyprotein expression in human HeLa and HepG2 cells induces severe morphological alterations and production of electron dense structures in the cytoplasm surrounded by membranes}

To gain more detail information on the subcellular changes induced by HCV polyprotein expression, we performed transmission electron microscopy (EM) analysis. HeLa cells were infected with VT7-HCV ${ }_{7.9}$ in the presence or absence of IPTG, and at $16 \mathrm{~h}$ p.i, infected and uninfected cells were collected and ultrathin sections visualized by EM at low and high magnification. While in cells infected with VT7-HCV 7.9 , in the absence of IPTG there are high number of immature (IVs) and intracellular mature (IMVs) forms of VACV virus, in cells infected with VT7$\mathrm{HCV}_{7.9}$ in the presence of IPTG fewer IVs and IMVs were observed, corroborating our previous finding that the expression of HCV proteins blocked VACV morphogenesis [12]. In addition, several morphological alterations were detected in cells expressing the HCV polyprotein when compared with uninfected cells (Fig. 2A) or with cells only expressing VACV proteins (Fig. 2B). The first 


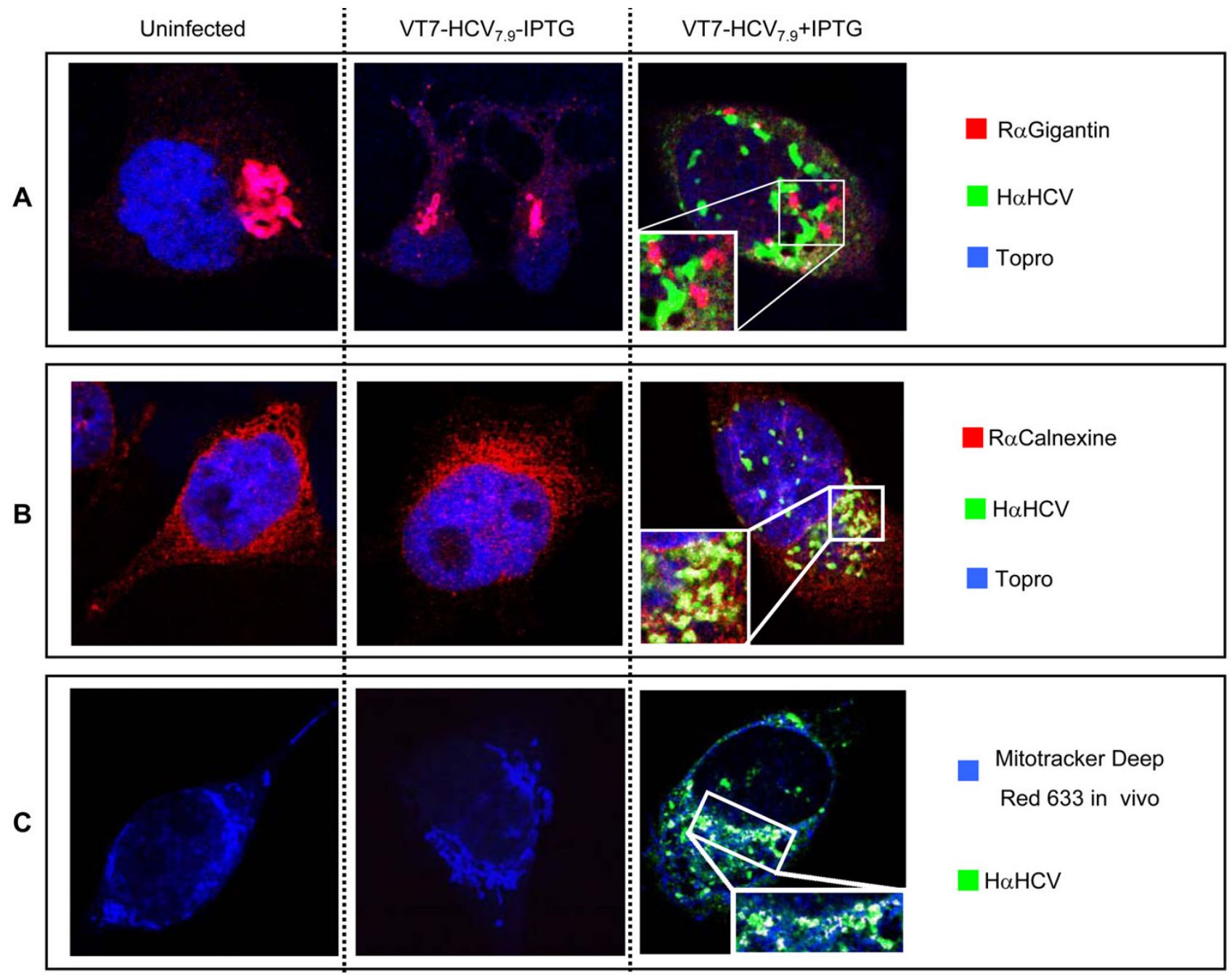

Figure I

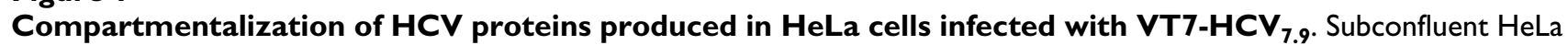
cells uninfected or infected at 5 PFU/cell with the recombinant VT7-HCV7.9 in the presence (+) or absence (-) of the inducer IPTG, were fixed at $24 \mathrm{~h}$ p.i, labelled with the corresponding primary antibody followed by the appropriate fluorescent secondary antibody and visualized by confocal microscopy. The antibodies or reagents used were $\mathrm{H} \alpha \mathrm{HCV}$ to detect HCV proteins; Topro-3 to detect DNA; R $\alpha$ Giantin to detect the Golgi complex (A); R $\alpha$ Calnexine to detect the endoplasmatic reticulum (B) and Mitotracker Deep Red 633 to detect mitochondria (C). The co-localization is shown with a higher resolution in the white square.

alteration seen was the loss of spatial organization of the ER, with vesicles embedded in a membrane matrix of circular or tightly undulating membranes, forming electron dense structures indicated as EDS (Fig. 2C and 2D). These cytoplasmic structures resemble those structures called "membraneous webs" that have been visualized in human hepatoma Huh7 cells expressing a subgenomic HCV replicon $[5,14,15]$. Other alterations observed were the presence of vacuoles (indicated as V) often surrounding the compact structures, as well as the presence of swollen mitochondria (indicated as m) (Fig. 2D and 2E).
Higher magnification of the electron dense structures in cells expressing the HCV polyprotein revealed membranes and tubular structures (indicated as TS) as part of the EDS (Fig. 2E).

Since hepatocytes are the main targets of HCV virus, we next analyzed if expression of HCV polyprotein from the VT7-HCV ${ }_{7.9}$ infected cells also affected the ultra-structure of hepatic cells. Thus, monolayers of a human hepatoblast cell line (HepG2) were infected with VT7-HCV 7.9 under the same conditions as for HeLa cells and processed at 16 

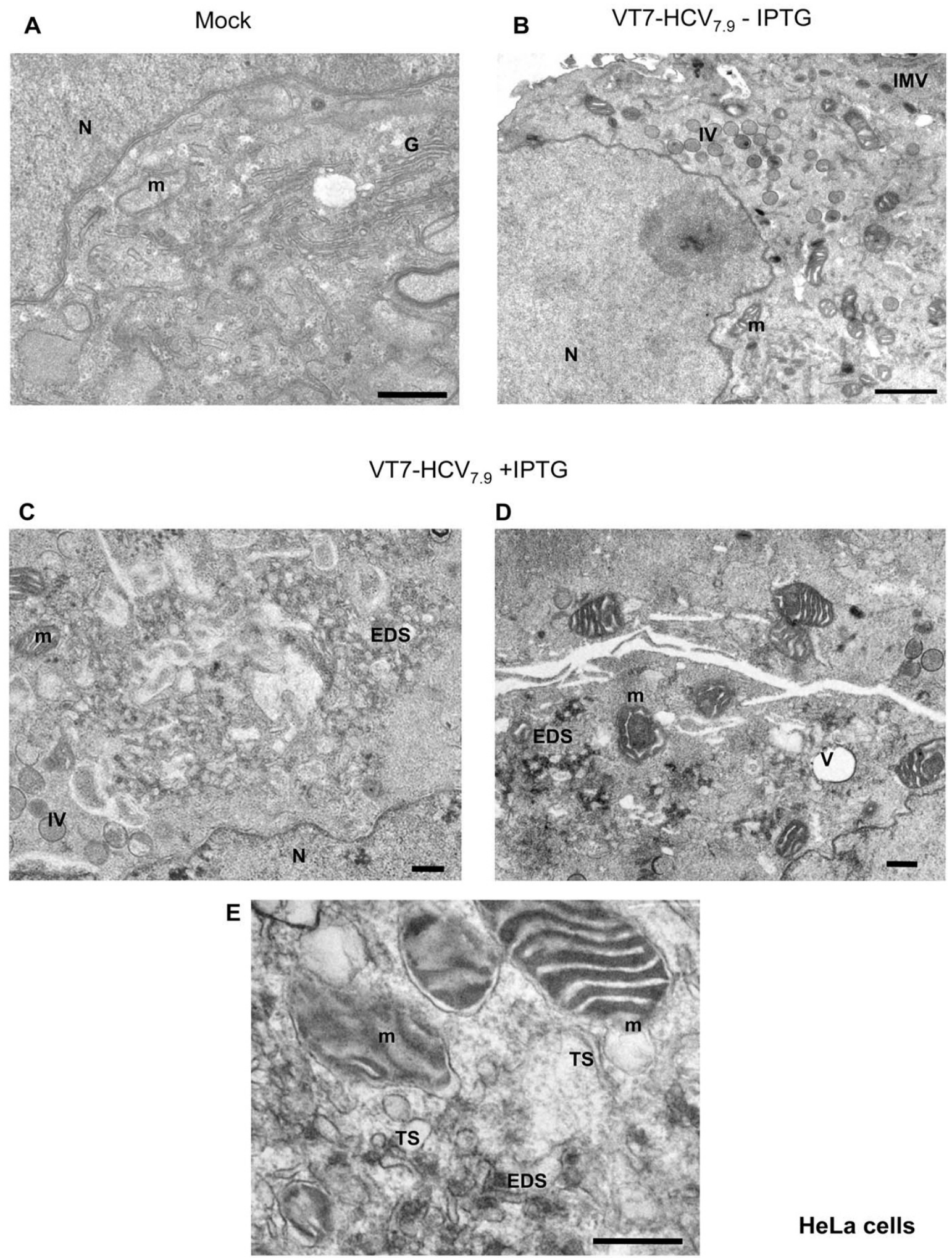

HeLa cells

Figure 2 (see legend on next page) 
Figure 2 (see previous page)

Alterations in the architecture of HeLa cells following expression of HCV proteins from VT7-HCV 7.9 seen by electron microscopy. HeLa cells uninfected or infected with the recombinant VT7-HCV7.9 in the presence or absence of the inducer IPTG, were chemically fixed at $16 \mathrm{~h}$ p.i and then processed for conventional embedding in an epoxy resin as described under Materials and Methods.A: Cellular architecture of uninfected HeLa cells. B: A general view of a cell infected with VT7-HCV7.9 in the absence of IPTG, showing the VACV forms IVs and IMVs. C and D: A general view of cells infected with VT7-HCV7.9 in the presence of IPTG, showing few IVs, large EDS, swollen mitochondria and vacuoles. E: High magnification of infected VT7-HCV7.9 cells in the presence of IPTG showing EDS with membranes, TS and swollen mitochondria with a protruding membrane. Note: Nucleus (N), mitochondria $(\mathrm{m})$, Golgi apparatus (G), immature virus (IV), intracellular mature virus (IMV), tubular structures (TS), electron dense structures in membranous webs (EDS). Bar: $500 \mathrm{~nm}$.

h p.i for EM analysis. In this cell line, similarly as in HeLa cells, the inducible expression of HCV proteins blocks VACV morphogenesis and induces the same alterations described above. In contrast to uninfected (Fig 3A) and infected hepG2 cells in absence of IPTG (Fig. 3B), in cells expressing HCV proteins we distinguish EDS in membranous webs (Fig. 3C and 3E), formation of large vacuoles (Fig. 3C and 3D), and also identified "virus like-particles" structures surrounded by membranes and dispersed in several areas of the cell cytoplasm (Fig. 3D).

\section{Immunogold electron microscopy revealed that HCV proteins are part of the electron dense and membranous structures}

To assure that the electron dense structures appearing in the cytoplasm of infected cells are the result of HCV polyprotein expression, we performed immunogold electron microscopy analysis with antibodies against HCV structural and nonstructural proteins (Fig. 4). Thus, HeLa cells were infected with $\mathrm{VT} 7-\mathrm{HCV}_{7.9}$ in the presence or absence of IPTG and at $16 \mathrm{~h}$ p.i, infected and uninfected cells were processed for immunogold labelling on ultrathin sections. Due to the fixation and embedding procedures used in immunostaining, the cell structures are less visible than by embedding in an epoxy resin. While in cells infected with VT7-HCV ${ }_{7.9}$ in absence of IPTG there was no specific labelling detected with the serum from an HCV-infected patient (Fig. 4A), in contrast, in antibody-reacted cells expressing HCV proteins most gold particles were concentrated into electron dense and membranous structures (Fig. 4B). Discrete labelling was observed in other parts of the cell cytoplasm. The localization of some of the nonstructural HCV proteins was determined using rabbit polyclonal antibodies against NS4B or NS5A proteins. The membranous and electron dense structures were also specifically recognized by antibodies against NS4B (Fig. 4C) and NS5A (Fig. 4D), indicating that both proteins are part of electron dense membrane-associated cytoplasmic complexes.

Since by confocal microscopy we observed co-localization between ER and HCV proteins in cells infected with VT7-
$\mathrm{HCV}_{7.9}$ in the presence of IPTG (see Fig. 1B), we performed immunogold labelling using a specific ER marker (mouse anti-PDI). As seen in Fig. 4E, strong labelling of ER was found in the membranous webs. These results suggest that the membranous webs are ER-derived structures. As the staining pattern corresponds to that obtained with the NS4B or NS5A proteins, the immunogold electron microscopy indicates that the ER is a site where these proteins are localized.

\section{HCV polyprotein expression results in mitochondrial dysfunction, as revealed by release of cytochrome c, loss of membrane potential and generation of reactive oxygen species (ROS)}

The detection by confocal microscopy of the presence of HCV proteins in the mitochondria (see Fig. 1C) suggests that HCV may regulate the mitochondria homeostasis. To confirm that, we evaluated different parameters such as, release of proapototic proteins including cytochrome $\mathrm{c}$, loss of mitochondrial membrane potential $(\Delta \Psi \mathrm{m})$ and production of reactive oxygen species (ROS), all hallmarks of mitochondrial dysfunction.

To determine whether HCV polyprotein expression from the VACV recombinant activates cytochrome c release, HeLa cells were infected with VT7- $\mathrm{HCV}_{7.9}$ in the presence or absence of IPTG, or treated with staurosporine (as a positive control). The cytochrome $\mathrm{c}$ release was detected by confocal microscopy. As shown in Fig. 5A, the cytochrome c remained confined to the mitochondria in both uninfected cells and VT7-HCV 7.9 infected cells in the absence of IPTG. However, in cells infected with VT7$\mathrm{HCV}_{7.9}$ in the presence of IPTG, there is a diffuse cytosolic pattern of cytochrome c staining, similarly as in cells treated with staurosporine, indicating that cytochrome $\mathrm{c}$ was released from the mitochondria.

Next we determine if HCV polyprotein expression affected the mitochondria membrane potential $(\Delta \Psi \mathrm{m})$. HeLa cells were infected either with VT7-HCV 7.9 in the presence or absence of IPTG, or treated with staurosporine. At 48 h p.i, cells were stained in vivo with a fluorescent mitochon- 
A

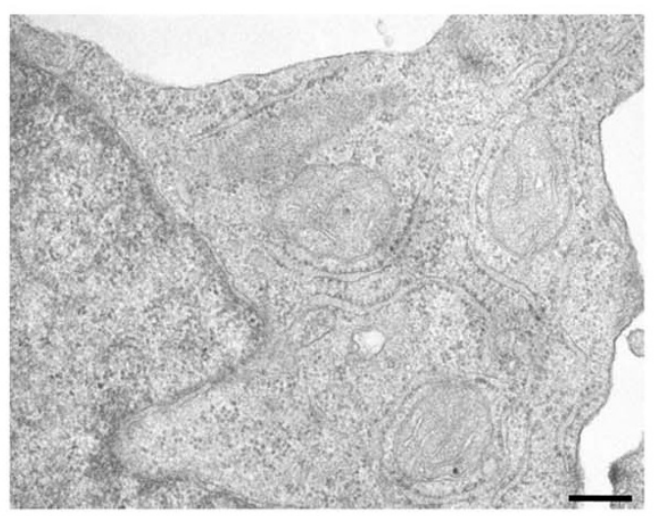

B $\quad$ VT7-HCV $7.9-$ IPTG

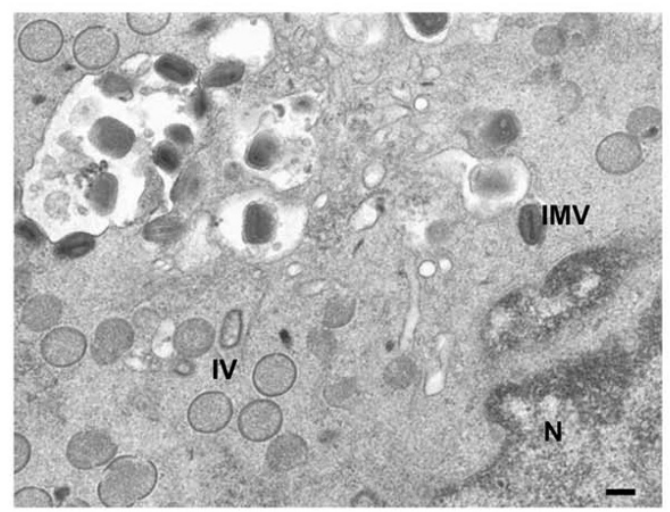

$$
\text { VT7- } \mathrm{HCV}_{7.9}+\mathrm{IPTG}
$$

C

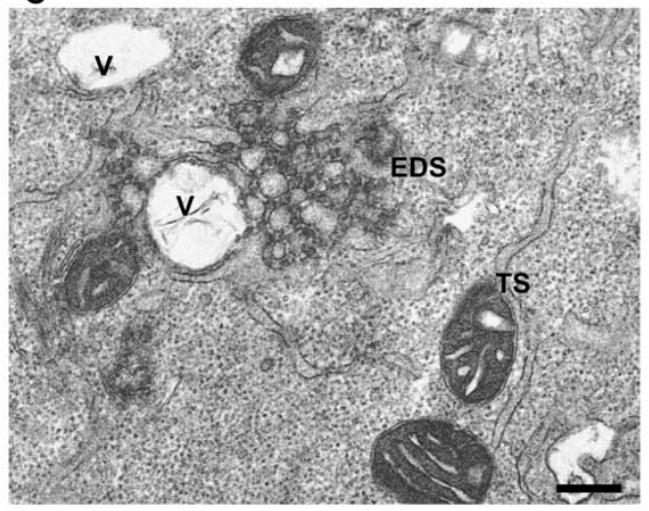

D

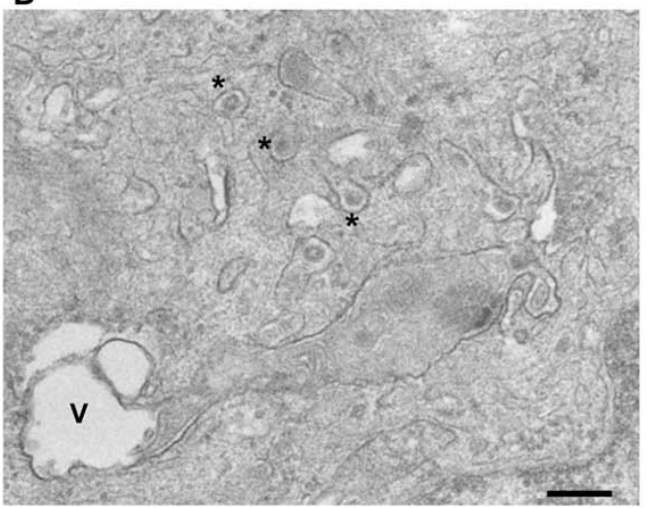

E

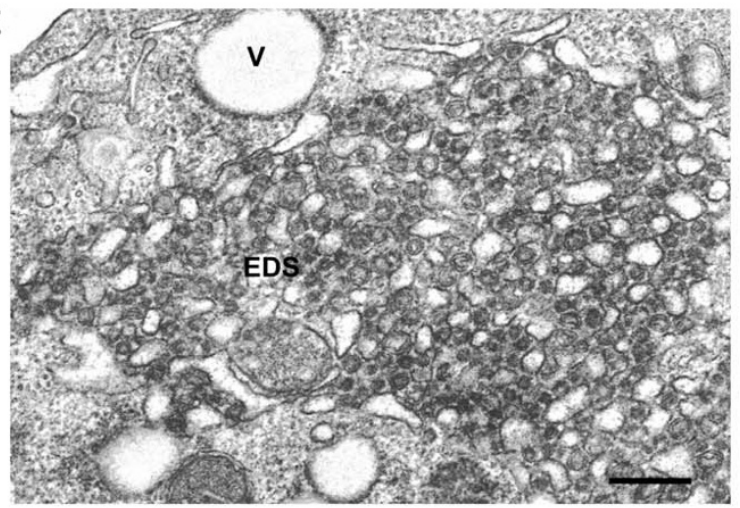

HepG2 cells

\section{Figure 3}

Hepatocyte cell alterations following infection of HepG2 with VT7-HCV7.9. HepG2 cells uninfected or infected with the recombinant VT7-HCV7.9 in the presence or absence of the inducer IPTG were chemically fixed at $16 \mathrm{~h}$ p.i and then processed for conventional embedding in an epoxy resin.A: Cellular architecture of uninfected HepG2 cells. B: A general view of a cell infected with VT7-HCV7.9 in the absence of IPTG, showing the VACV forms IVs and IMVs.C, D and E: A general view of a cell infected with VT7-HCV7.9 in the presence of IPTG, showing large EDS surrounded by vacuoles and the presence of "virus-like particles" surrounded with membranes $(*)$. Note: Vacuole $(\mathrm{V})$ and electron dense structures in membranous webs (EDS). Bar: $200 \mathrm{~nm}$. 

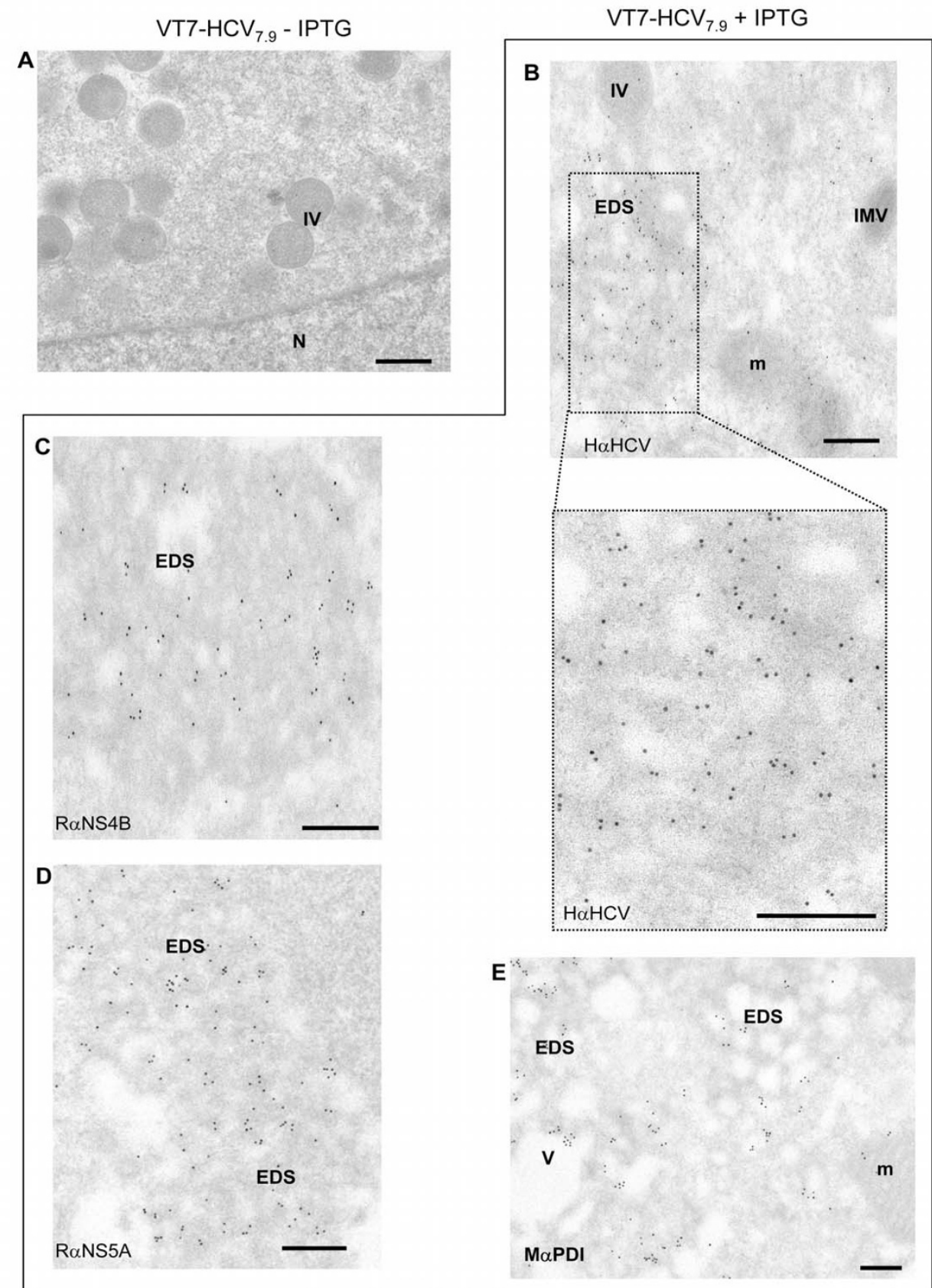

\section{Figure 4}

Immunogold electron microscopy analysis of the localization of HCV proteins in VT7-HCV 7.9 infected HeLa cells. HeLa cells infected with VT7-HCV7.9 in the presence or absence of IPTG were chemically fixed, quickly frozen in liquid propane and then processed at low temperature in Lowicryl K4M resin. Immunogold labelling was performed with different antibodies. A: Cells infected with VT7-HCV7.9 in the absence of IPTG reacted with a serum from an HCV-infected patient.B: Cells infected with VT7-HCV7.9 in the presence of IPTG reacted with a serum from an HCV-infected patient C: Cells infected with VT7-HCV7.9 in the presence of IPTG reacted with a rabbit polyclonal anti-NS4B. D: Cells infected with VT7-HCV7.9 in the presence of IPTG reacted with a rabbit polyclonal anti-NS5A. E: Cells infected with VT7-HCV7.9 in the presence of IPTG reacted with a mouse monoclonal antibody anti-PDI. Note: Electron dense structures in membranous webs (EDS); mitochondria (m), immature virus (IV), intracellular mature virus (IMV), nucleus (N) and Vacuole (V). Bar: $250 \mathrm{~nm}$. 


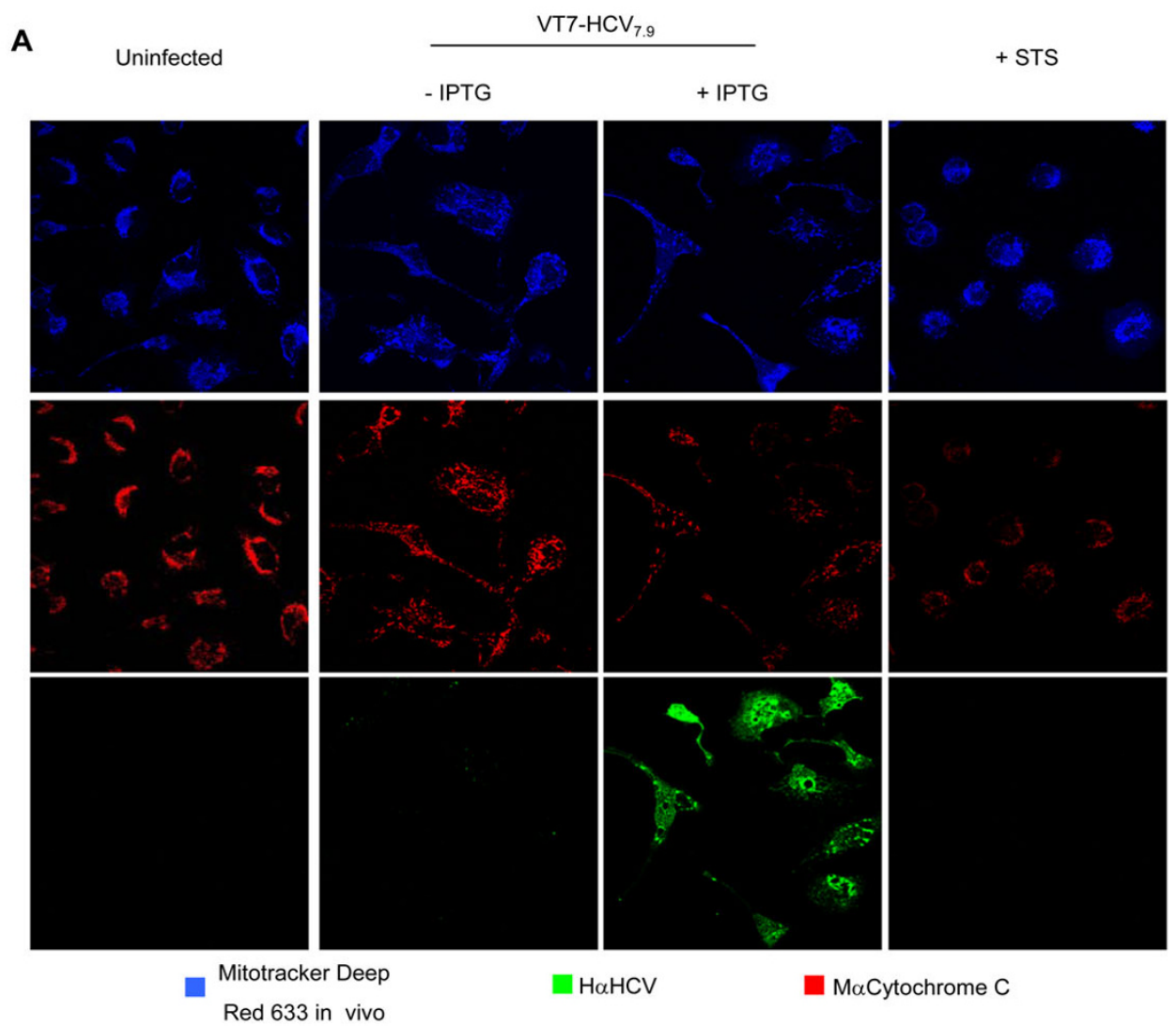

B

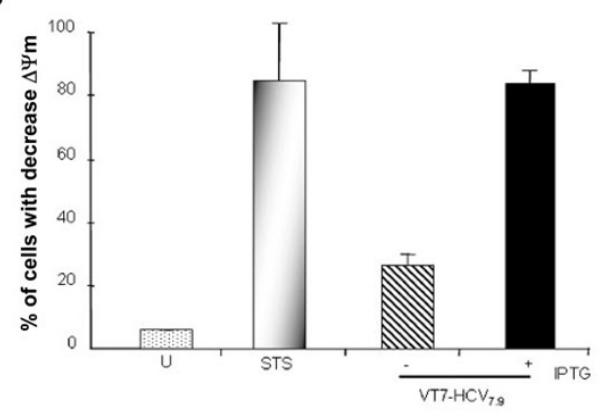

C

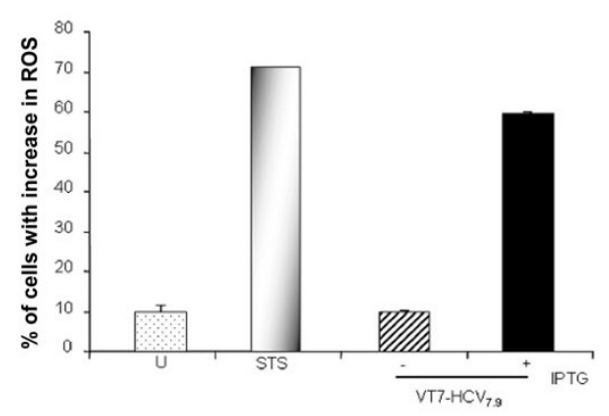

\section{Figure 5}

HCV polyprotein expression induced dysfunction of the mitochondria. A: HeLa cells uninfected or infected at 5 PFU/ cell with the recombinant VT7-HCV7.9 in the presence or absence of IPTG were labelled in vivo at $24 \mathrm{~h}$ p.i with Mitotracker deep red (blue) to detect the mitochondria, with an anti-cytochrome $c$ (red) antibody and with the serum from an HCVinfected patient to detect $\mathrm{HCV}$ proteins. Cells treated with staurosporine at $0.5 \mu \mathrm{M}$ for $16 \mathrm{~h}$ were used as positive control. B: HeLa cells were either infected at 5 PFU/cell with the recombinant VT7-HCV7.9 in the presence or absence of IPTG, or treated with staurosporine at $0.5 \mu \mathrm{M}$ for $16 \mathrm{~h}$. At $48 \mathrm{~h}$ p.i, the mitochrondrial membrane potential $(\Delta \Psi \mathrm{m})$ was determined quantifying TMRE fluorescence. C: HeLa cells were either infected at 5 PFU/cell with the recombinant VT7-HCV7.9 in the absence or presence of IPTG or treated with staurosporine at $0.5 \mu \mathrm{M}$ for $16 \mathrm{~h}$. At $48 \mathrm{~h}$ p.i, the uninfected and infected cells were stained with dihydroethidium (2-HE) and subjected to flow cytometry. Note: STS: staurosporine. 
drion-specific dye, TMRE $[16,17]$, and analysed by flow cytometry. The loss of the $\Delta \Psi \mathrm{m}$ was assessed by the ability of the mitochondria to take up TMRE. As shown in Fig. 5B, FACS analysis demonstrated a higher proportion of cells with decreased $\Delta \Psi \mathrm{m}(\Delta \Psi \mathrm{m}$ Low) in HCV polyprotein expressing cells and in staurosporine treated cells, in contrast with cells infected with the VT7- $\mathrm{HCV}_{7.9}$ in the absence of IPTG or in uninfected cells. These results indicate the ability of the HCV proteins to disrupt the mitochondria membrane potential in HeLa cells.

As mitochondrial dysfunction is also characterized by the generation of reactive oxygen species (ROS) [18], we investigated whether HCV polyprotein expression triggered the generation of ROS. HeLa cells were infected with VT7- $\mathrm{HCV}_{7.9}$ in the presence or absence of IPTG and at 48 h p.i, cells were stained with dihydroethidium (2-HE) and subjected to flow cytometry [19]. As shown in Fig. 5C, there is clearly production of ROS, as revealed by an increase in ethidium staining of DNA in HeLa cells infected with VT7-HCV ${ }_{79}$ in the presence of IPTG. In contrast, ROS production was significantly lower (about $10 \%$ ) in both uninfected cells and VT7-HCV 7.9 infected cells in the absence of IPTG.

The above results demonstrate that HCV proteins induce mitochondrial dysfunction evidenced by the release of cytochrome $\mathrm{c}$, mitochondrial membrane depolarization and generation of ROS.

\section{Expression of HCV proteins induces apoptosis through activation of initiator and effector caspases}

It has been reported in hepatic cells that expression of structural and nonstructural proteins from HCV cDNA [20] or from full-length RNA [21], can lead to apoptotic cell death, which could be an important event in the pathogenesis of chronic HCV infection in humans. We have previously shown by an ELISA-based assay that the inducible expression of HCV proteins from VT7-HCV 7.9 triggers apoptosis [12]. In view of the severe cellular damage caused by polyprotein expression in VT7- $\mathrm{HCV}_{7.9}$ infected cells, we wished to extend our previous observation by characterizing the apoptotic pathways in this virus-cell system. We first performed a qualitative estimation of apoptosis in HeLa cells infected with VT7- $\mathrm{HCV}_{7.9}$ in the presence or absence of IPTG. By phase contrast microscopy and DNA staining analysis we observed that cells expressing HCV polyprotein developed at $24 \mathrm{~h}$ p.i characteristic morphological changes of apoptosis, as defined by cell shrinkage, granulated appearance, membrane bledding and chromatin condensation (not shown). Such morphological changes were not observed in cells infected with VT7-HCV 7.9 in the absence of the inducer.
To quantify the extent of apoptosis, DNA content was analyzed by flow cytometry after permeabilization and labelling with the DNA-specific fluorochrome propidium iodide. As shown by flow cytometry, $78 \%$ of HeLa cells infected with VT7-HCV 7.9 in the presence of IPTG were apoptotic in contrast with the $26 \%$ determined when cells were infected with VT7- $\mathrm{HCV}_{7.9}$ in the absence of the inducer (Fig. 6A).

Since DNA fragmentation represents a late apoptotic event, we analyzed the activation of effector caspases as a previous stage in the induction of apoptosis. Apoptotic caspases are activated by a proteolytic cascade resulting in the cleavage of critical cellular substrates, including lamins and poly (ADP-ribose) polymerase (PARP). By immunoblot analysis using anti-poly-(ADP-ribose) polymerase (PARP) antibody, which recognizes the full (116 kDa) and cleaved ( $89 \mathrm{kDa}$ ) form of PARP, we determined that the expression of HCV proteins induced the activation of effector caspases, as revealed by the presence of the 89 $\mathrm{kDa}$ cleaved form in cell extracts from VT7-HCV 7.9 infected cells in the presence of IPTG. This activation was similar to that obtained in cells expressing the apoptotic inducer protein kinase PKR used as positive control. In contrast, minimal PARP cleavage product was observed in cell extracts from both uninfected cells and VT7- $\mathrm{HCV}_{7.9}$ infected cells in the absence of IPTG (Fig. 6B, left panel). The general caspase inhibitor zVAD-fmk blocked completely activation of caspases, as revealed by PARP cleavage and by ELISA (Fig. 6B).

Having established the activation of downstream effector caspases by HCV polyprotein expression, we set out to analyze the upstream or initiator caspases that exert regulatory roles, like caspase- 8 and 9 . Western blot analysis of lysates from VT7- $\mathrm{HCV}_{7.9}$ infected cells in the presence of IPTG using an antibody that recognizes the active caspase8 , detected a cleaved product of $43 \mathrm{kDa}$, which corresponds to the active subunit of caspase- 8 , and a product of $57 \mathrm{kDa}$, which corresponds to pro-caspase-8 (Fig. 6C, left panel). The same size cleaved product was also observed in cell lysates from VV-PKR infected cells used as positive control. In contrast, in uninfected cells or in cells infected with VT7-HCV ${ }_{7.9}$ in the absence of IPTG only the pro-caspase- 8 product was observed. Caspase- 8 activation and apoptosis induction in cells infected with VT7- $\mathrm{HCV}_{7.9}$ in the presence of IPTG was strongly inhibited by pretreating the cells with the specific caspase- 8 inhibitor zIETD-fmk (Fig. 6C, right panel). These results showed that expression of HCV proteins induces caspase-8-mediated apoptosis.

To define if the mitochondrial route could also be involved in the apoptosis induced by HCV polyprotein expression, we analyzed by Western blot the activation of 

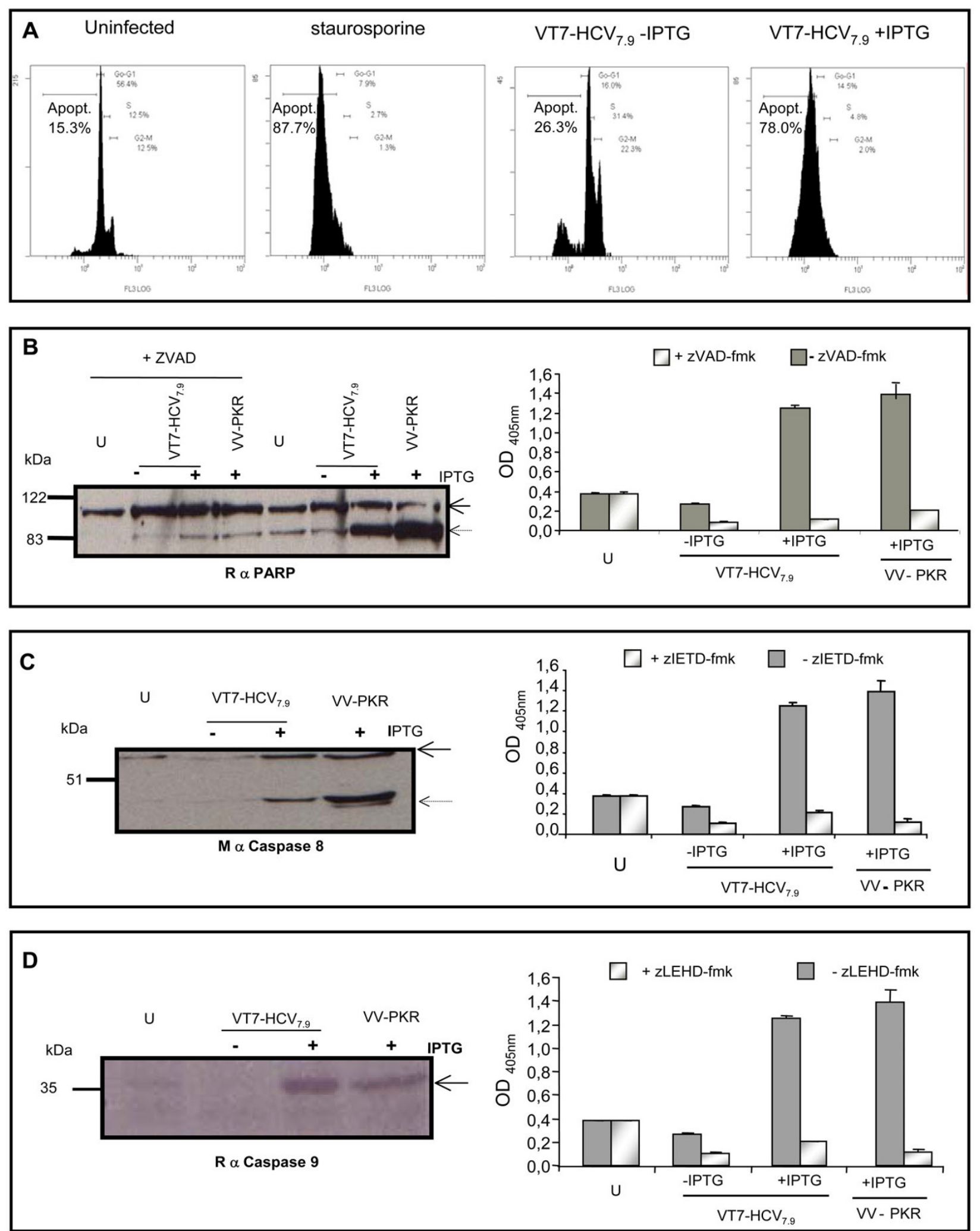

Figure 6 (see legend on next page) 
Figure 6 (see previous page)

HCV proteins induced apoptosis in a caspase-dependent manner. A: Extent of apoptosis. HeLa cells were infected at 5 PFU/cell with the recombinant VT7-HCV7.9 in the presence or absence of IPTG. At $24 \mathrm{~h}$ p.i, uninfected and infected cells where fixed with an $\mathrm{EtOH} 70 \%-P B S$ solution, washed and stained with propidium iodide (PI) as explained in Material and Methods. The cell cycle was measure by flow cytometry. Cells treated with staurosporine at $0.5 \mu \mathrm{M}$ for $16 \mathrm{~h}$ were used as positive control. B: Activation of effector caspases. HeLa cells were infected at 5 PFU/cell with the recombinant VT7-HCV7.9 in the presence (+) or absence (-) of IPTG individually or in combination with a general caspase inhibitor, zVAD-fmk at $50 \mu M$. Cell lysates from uninfected and infected cells were collected at $48 \mathrm{~h}$ p.i and separated on a I $2 \%$ SDS-PAGE for immunoblot analysis using an antibody that recognizes full-length $(116 \mathrm{kDa})$ and cleavage-PARP $(89 \mathrm{kDa})$ (left panel) or used for the quantification of the apoptotic levels by ELISA (right panel). C: Caspase-8 activation. HeLa cells were infected at 5 PFU/cell with the recombinant VT7-HCV7.9 individually or in combination with a caspase-8 inhibitor, zIEDT-fmk at $50 \mu \mathrm{M}$, in the presence (+) or absence (-) of IPTG. Uninfected and infected cell lysates were collected at $48 \mathrm{~h}$ p.i. and separated on a I2\% SDS-PAGE for immunoblot analysis using an antibody that recognizes procaspase- $(57 \mathrm{kDa})$ and active-caspase-8 (43 kDa) (left panel) or used for the quantification of the apoptotic levels by ELISA (right panel). D: Caspase- 9 activation. HeLa cells were infected at 5 PFU/ cell with the recombinant VT7-HCV7.9 individually in the presence (+) or absence (-) of IPTG or in combination with a caspase-9 inhibitor, zLEHD-fmk at $50 \mu \mathrm{M}$. Uninfected and infected cell lysates were collected at $48 \mathrm{~h}$ p.i and separated on a $12 \%$ SDS-PAGE for immunoblot analysis using an antibody that recognizes the active-caspase 9 ( $37 \mathrm{kDa}$ ) (left panel) or used for the quantification of the apoptotic levels by ELISA (right panel). Cells infected with the inducible VV-PKR were used as positive control.

caspase-9. Lysates from uninfected and VT7$\mathrm{HCV}_{7.9}$ infected cells in the presence or absence of IPTG were reacted with a specific antibody that detects only the cleaved product of $37 \mathrm{kDa}$ corresponding to the active subunit of caspase-9 (Fig. 6D). The active caspase-9 was detected in lysates from cells expressing the HCV proteins in contrast to lysates from uninfected cells or from cells infected with VT7-HCV 7.9 in the absence of IPTG (Fig. 6D, left panel). The activation of caspase- 9 was confirmed after quantification by ELISA of the extent of the apoptosis induced by HCV proteins in the presence or absence of the specific caspase-9 inhibitor zLEHD-fmk. Severe inhibition was obtained by pretreating cells infected with VT7$\mathrm{HCV}_{7.9}$ in the presence of IPTG with zLEHD-fmk (Fig. 6D, right panel). The above observations establish that HCV proteins activate initiator and effector caspase-dependent death processes, with involvement of the two caspase 8 and 9 pathways.

\section{Identification of differentially expressed human genes in cells expressing HCV proteins}

Since identification of host genes triggered in response to HCV proteins is important to understand the pathogenic effects of HCV virus, we performed a microarray analysis to profile transcripts differentially expressed in HeLa cells infected with VT7-HCV ${ }_{7.9}$ that inducible express HCV proteins. A comparative analysis of genes regulated was done after subtracting the values obtained from cells infected in the absence of the inducer IPTG versus values obtained in the presence of IPTG. Hybridization analysis revealed that at 6 hours after induction of HCV polyprotein expression 231 genes were differentially regulated. About $71 \%$ of these genes appear upregulated whereas the remaining $29 \%$ were downregulated. At $16 \mathrm{~h}$ post-induction the number of transcripts that passed the filtering conditions is significantly reduced. 81 genes were differentially expressed at this time and only $43 \%$ of them appear upregulated (see Additional file 1). The reduction observed at $16 \mathrm{~h}$ p.i correlated with the cell damage induced by HCV proteins in the infected cells, and hence only the data from $6 \mathrm{~h}$ p.i will be considered. Real time RT-PCR was used to verify the transcriptional change in selected genes, as detected by microarray (Table 1) since we have previously verified that microarray data correlated well with RT-PCR quantification $[22,23]$.

Most of the biochemical and morphological changes induced by HCV proteins described in this study were reflected in the gene expression profiling. Genes involved in apoptosis, oxidative stress, mitochondrial functions or membrane transport were upregulated by HCV proteins (Table 2). Moreover, genes encoding proteins implicated in lipid metabolism, DNA binding, cell cycle, signalling and inflammatory response changed in expression throughout the infection.

Table I: Confirmation of microarray data by real time RT-PCR

\begin{tabular}{|c|c|c|c|c|}
\hline \multirow[t]{3}{*}{ Gene product } & \multicolumn{4}{|c|}{ Fold change by: } \\
\hline & \multicolumn{2}{|c|}{ Microarray } & \multicolumn{2}{|c|}{ RT-PCR } \\
\hline & $t=6$ & $t=16$ & $t=6$ & $t=16$ \\
\hline H3F3B & 2.65 & 1.39 & 2.07 & 2.28 \\
\hline HIST2H4A & 3.67 & 8.45 & 3.82 & 8.65 \\
\hline IL6 & 5.67 & 7.49 & 8.16 & 10.1 \\
\hline
\end{tabular}


Table 2: Microarray analysis revealed characteristic changes in gene expression profiling of HeLa cells during HCV protein expression from VT7-HCV 7.9 (6 h p.i)

\section{GENE DESCRIPTION}

\section{Apoptosis}

RAD2I homolog (S. pombe)

Protein phosphatase 2 (formerly $2 \mathrm{~A}$ ), catalytic subunit, alpha isoform

Hepatocellular carcinoma-associated antigen 66

Glucose regulated protein, $58 \mathrm{kD}$

Insulin-like growth factor I receptor

Sphingosine kinase type 2 isoform

\section{Mitochondrial functions}

ATP synthase, $\mathrm{H}+$ transporting, mitochondrial $\mathrm{FI}$ complex

ATP synthase, $\mathrm{H}+$ transporting, mitochondrial $\mathrm{FI}$ complex, $\mathrm{O}$ subunit

Complement component I, q subcomponent binding protein

$\mathrm{NADH}$ dehydrogenase (ubiquinone) I beta subcomplex, 9 (22 kD, B22)

Voltage-dependent anion channel I

Surfeit I

Solute carrier family 25 , member 10

\section{Lipid metabolism/Oxidative stress}

DnaJ (Hsp40) homolog, subfamily C, member 10

Glutathione peroxidase 4 (phospholipid hydroperoxidase)

Fatty acid binding protein 5 (psoriasis-associated)

Nuclear receptor subfamily 5 , group A, member 2

Peroxiredoxin I

StAR-related lipid transfer (START) domain containing 4

Cytochrome P450, family 19, subfamily A, polypeptide I

Glutathione S-transferase MI

ATPase, class I, type 8B, member 4

24-dehydrocholesterol reductase

Peripheral myelin protein 2

Glucose-6-phosphate dehydrogenase

\section{Membrane transport}

Clathrin, light polypeptide (Lca)

Centaurin, gamma 2

Adaptor-related protein complex 3 , sigma I subunit

Coatomer protein complex, subunit beta

USOI homolog, vesicle docking protein (yeast)

SEC24 related gene family, member $B$ (S. cerevisiae)

Paralemmin

Adaptor-related protein complex 2, mu I subunit

Lectin, mannose-binding 2-like

Reticulon 4

\section{DNAbinding/Cell cycle}

Histone cluster I, H2am

Histone cluster I, H4h

Histone cluster 2, $\mathrm{H} 4 \mathrm{a}$

$\mathrm{H} 2 \mathrm{~A}$ histone family, member $\mathrm{Z}$

Histone cluster I, H4d

$\mathrm{H} 3$ histone, family $3 \mathrm{~B}(\mathrm{H} 3.3 \mathrm{~B})$

$\mathrm{CDC} 28$ protein kinase regulatory subunit 2

Karyopherin alpha 2 (RAG cohort I, importin alpha I)

Nuclear receptor subfamily 5 , group $A$, member 2

\section{Inflammatory response/Signalling}

Interleukin 6 (interferon, beta 2)

Chloride intracellular channel I

Neuroepithelial cell transforming gene I

Interleukin-I receptor-associated kinase I

GENBANK ACCESSION GENE SYMBOL FOLD-CHANGE

NM 006265

NM 002715

NM 018428

NM 005313

NM 000875

BC006161

NM 005174

NM 001697

NM 001212

NM 005005

NM 003374

NM 003172

NM 012140

AK027647

NM 002085

NM 001444

NM 003822

NM 002574

AK054566

NM 031226

NM 00056I

NM 024837

NM 014762

NM 002677

NM 000402

NM 007096

NM 014914

NM 001284

NM 016451

NM 003715

NM 006323

NM 002579

NM 004068

NM 030805

AFI48537

NM 003514

NM 003543

NM 003548

NM 002106

NM 003539

AF218029

NM 001827

NM 002266

NM 003822

NM 000600

NM 001288

BC010285

NM 001569
RAD2I

PPP2CA

HCA66

PDIA3

IGFIR

SPHK2

2,93

2,07

2,07
1,7

1,67

$-1,64$

$-I, 87$

ATP5CI

2,6

ATP5O $\quad \mathbf{2 , 4 8}$

CIQBP $\quad \mathbf{2 , 2 7}$

NDUFB9 $\quad 2,21$

VDACI $\quad \mathbf{1 , 8 6}$

SURFI $\quad 1,69$

SLC25AIO

DNAJCIO $\quad \mathbf{3 , 6 8}$

GPX4 $\quad 2,05$

FABP5 $\quad \mathbf{I , 8 I}$

NR5A2 I,8 I

PRDXI I,7I

STARD4 $\quad 1,63$

CYPI9AI $\quad \mathbf{1 , 5 7}$

GSTMI $\quad-1,65$

ATP8B4 $\quad-1,58$

DHCR24 $\quad-\mathbf{I}, 8 \mathbf{I}$

PMP2 $\quad-1,84$

G6PD $\quad-\mathbf{2 , 3 8}$

CLTA

CENTG2

AP3SI

COPBI

USOI

SEC24B

PALM

AP2MI

LMAN2L

RTN4

3,05

2,1

1,76

1,73

1,73

1,72

1,67

$-1,85$

$-1,89$

I,64

HISTIH2AM $\quad \mathbf{7 , 0 3}$

HISTIH4H $\quad \mathbf{6 , 0 9}$

HIST2H4A $\quad 3,67$

H2AFZ $\quad 3,58$

HISTIH4D $\quad \mathbf{2 , 6 8}$

H3F3B $\quad 2,65$

CKS2 2,21

KPNA2 $\quad 1,78$

NR5A2 I,8I

$\begin{array}{ll}\text { IL6 } & \mathbf{5 , 6 7} \\ \text { CLICI } & \mathbf{2 , 8 I} \\ \text { NETI } & \mathbf{2 , 2 8} \\ \text { IRAKI } & \mathbf{2 , 2 3}\end{array}$


Table 2: Microarray analysis revealed characteristic changes in gene expression profiling of HeLa cells during $\mathrm{HCV}$ protein expression from VT7-HCV 7.9 (6 h p.i) (Continued)

\begin{tabular}{llll}
\hline CDC42 small effector I & NM 020239 & CDC42SEI & I,73 \\
Others & & & DDX5 \\
DEAD (Asp-Glu-Ala-Asp) box polypeptide 5 & NM 004396 & TPRKB & $\mathbf{2 , 9 I}$ \\
TP53RK binding protein & NM 016058 & TCPI I & $\mathbf{2 , 4 3}$ \\
T-complex I & NM 030752 & EIF4E & $\mathbf{2 , 2 3}$ \\
Eukaryotic translation initiation factor 4E & NM 001968 & OLFMI & $\mathbf{2 , 0 3}$ \\
Olfactomedin I & NM 014279 & LDOCI & $-\mathbf{I , 6 6}$ \\
Leucine zipper, down-regulated in cancer I & AY012317 & HTRA3 & $-\mathbf{1 , 8 4}$
\end{tabular}

Genes implicated in apoptosis such as RAD21, PPP2CA, HCA66 or PDIA3 were upregulated whereas antiapoptotic genes IGF1R or SPHK2 were downregulated by HCV proteins. Interestingly, it has been described that HCA66 is able to modulate selectively Apaf- 1 dependent apoptosis increasing downstream caspase activity following cytochrome c release from the mitochondria [24], an event observed during the inducible expression of HCV proteins in our virus-cell system. Within the group of genes related with mitochondrial functions, the C1QBP and SLC25A10 transcripts have been correlated with HCV infection. C1QBP gene appears upregulated in liver biopsies from acutely HCV-infected chimpanzees whereas downregulation of SLC25A10 alters mitochondrial and cellular status resulting in altered susceptibility of hepatic cells to apoptosis [25].

HCV proteins also induced disturbance in the expression of lipid metabolism and oxidative stress. Upregulation of GPX4, PRDX1 and CYP19A1 genes have been previously detected in biopsies of HCV infected chimpanzees or in human hepatocellular carcinoma (HCC) samples [2527]. In contrast, it was reported that GSTM1 null genotype may facilitate HCV infection becoming chronic [28], and also this gene was downregulated in liver cells expressing entire HCV ORF [29]. Glucose-6-phosphate dehydrogenase (G6PD) activity was inhibited in hyperplastic liver as well as in HCC [30].

In agreement with the alterations and formation of electron dense structures observed in infected cells expressing the HCV polyprotein, genes such as CLTA, CENTG2 or AP3S1, which are closely related with the membrane dynamics, were upregulated. Moreover, ER-resident proteins like DNAJC10 and Reticulon 4 (RTN4), which modulate the ER morphology under stress conditions, also appear activated in HCC samples [31,32]. Gene encoding DNA binding proteins such as HIST1HA2M, HIST1H4H, HIST2H4A, H2AFZ and HIST1H4D, or cell cycle transcripts (CKS2 or KPNA2), were consistently upregulated. Specific increases in histones and cyclin genes were mark- ers of proliferative changes detected in the liver of HCV infected chimpanzees [25,33].

Other genes that have been associated with HCV infection and were differentially expressed in our system are CLIC1, NET1, IRAK1, DDX5, TPRKB, TCP1, OLFM1, LDOC1 and HTRA3. CLIC1 gene was upregulated in liver biopsies from infected chimpanzees [25], whereas DDX5 helicase has homology with DDX3, which plays an important role in HCV replication [34]. Relative high levels of NET1 and IRAK1 were reported in HCC [35,36]. Genes encoding for proteins TPRKB, T-Complex 1 (TCP1), Olftactomedin 1 (OLFM1), LDOC1 and HTRA3 have been implicated positive or negatively in cancer progression. TPRKB protein acts as a potential inhibitor of the binding of p53-related protein kinase PRPK to p53 [37], whereas T-Complex 1 and Olftactomedin 1 promote proliferation of cancer cells $[38,39]$. On the other hand, it has been suggested that the downregulation of LDOC1 and HTRA3 genes may play an important role in the development and/or progression of some cancers $[40,41]$.

Overall, the association of the gene expression profile obtained after induction of HCV proteins in VT7-HCV 7.9 infected HeLa cells with genomic changes in HCV pathogenesis highlights the biological significance of the morphological and biochemical events identified in this study.

\section{Discussion}

Various in vitro model systems have been developed to study the role of HCV polyprotein expression on host cell responses [4,6,42-45]. However, only recently was described a system that allows the growth of HCV in cultured cells $[7,9]$. Although these systems produced infectious HCV, the virus yields are low, not all cells become infected and the virus growth is only observed in certain cell lines. In this study we used the poxvirus-based system because it allowed the regulated expression of the nearly entire HCV polyprotein (except the C-terminal part of NS5B) in a wide range of cell types that efficiently support the VACV infection [46]. Confocal (CM) and electron 
microscopy (EM) were used to determine the subcellular localization of HCV proteins and the intracellular changes that occurred during the course of infection.

Comparable to previous analysis of HCV proteins expressed in culture cells $[47,48]$, the HCV polyprotein expressed from the VT7- $\mathrm{HCV}_{7.9}$ recombinant virus in the presence of the inducer IPTG, was localized largely in the cytoplasm, with a reticular/punctuate distribution that was more intense in the perinuclear area. In the course of infection there is disruption of the Golgi apparatus and co-localization between ER markers and HCV proteins. Partial co-localization between HCV and mitochondrial proteins was also detected. EM analysis showed the induction of membrane alterations similar to those found by other groups in cell-culture systems $[15,48]$ or in human and primate liver biopsies [49-51]. The main structures observed in infected HeLa and hepatic HepG2 cells were the formation of cytoplasmic "membrane webs", similar to those observed by Egger et al. [15]. These appear as electron dense structures (EDS) dispersed in several areas of the cell cytoplasm. As revealed by immunofluorescence, EM and immunoelectron microscopy (IEM) there is a clear loss of ER organization and concentration of the gold particles around the membranous webs. The electron dense structures were coated with an outer membrane connected to the ER membrane, where it has been described that HCV envelope proteins (E1 and E2) and nonstructural proteins are localized $[48,52,53]$. In infected cells expressing the HCV polyprotein we detected by EM the emergence of some "virus-like particles" structures. The shape of these structures seemed typical of mature virions of flavivirus [54]. Their size of $40 \mathrm{~nm}$ are similar to the virion-like structures observed in HeLa cells transfected with the full-length sequence of the HCV genome [6], but slightly smaller than the $55-\mathrm{nm}$ virus-like particles recovered from the circulation on an HCVinfected host [55]. Nonetheless, they are consistent with the size estimated for chimpanzee infectivity in a filtration study [56] and the size of a tissue culture-derived virus like particle [57]. We failed to detect HCV particles with enclosed envelopes corresponding to the full viral particles, probably because of removal of the $5^{\prime}$ and 3 ' terminal regulatory regions of $\mathrm{HCV}$ genome in $\mathrm{VT} 7-\mathrm{HCV}_{7.9}$, the lack of an entire NS5B protein and/or because the process of envelope acquisition is slow or transient and affected by specific cellular host protein(s) [58].

NS4B and NS5A expressed from the near full-length HCV genome produced strong labelling concentrated in the cytoplasm and were associated with the membranous webs. While the significance of the observed membrane alterations induced by HCV proteins cannot be assessed, it has been recently proposed that HCV genome synthesis occurs at lipid droplets-associated sites attached to the ER in virus-infected cells $[59,60]$ and that HCV assembly and maturation occurs in the ER and post-ER compartments [61]. Hence, the observations that NS4B and NS5A proteins are associated with the membranous web and that the same structure is found during HCV replication in chimpanzee liver, make the membranous web, a good candidate to act as the replication complex. In agreement with previous observations [61-63], our results provide evidence that the Golgi complex and the ER are subcellular compartments directly involved in HCV morphogenesis.

Other cellular alteration observed by EM in HeLa and HepG2 cells expressing the HCV polyprotein was the presence of swelling mitochondria, a phenomenon that has been previously described in patients with chronic HCV [64]. Since partial co-localization between HCV proteins and mitochondrial markers was also detected by immunofluorescence in our VACV system, here we characterized biochemically to what extent HCV polyprotein expression alter mitochondrial homeostasis. We observed by $\mathrm{CM}$ that in HeLa cells infected with VT7-HCV ${ }_{7.9}$ in the presence of the inducer IPTG there is release of cytochrome $\mathrm{c}$ from the mitochondria. This release correlates with the disruption of the mitochondrial membrane potential, as revealed by the high proportion of cells with decreased $\Delta \Psi \mathrm{m}$, and by the high levels of ROS. It has been reported that some $\mathrm{HCV}$ proteins, in addition to the ER, localize in the mitochondria disturbing its function. The structural core protein targets the mitochondria and increases $\mathrm{Ca}^{2+}$ dependent ROS production $[65,66]$. NS4A, when inducibly expressed in HepG2 transfected cells, is located in the mitochondria and is implicated in the loss of $\Delta \Psi \mathrm{m}$ [67], while when expressed from an HCV RNA replicon it forms a complex with NS3 changing the intracellular distribution of this organelle, triggering mitochondrial damage as evidence by the collapsed $\Delta \Psi \mathrm{m}$ and by the release of cytochrome $\mathrm{c}$ into the cytoplasm [13]. Although we can not assign the mitochondrial disturbance function to any HCV protein expressed in our system, it seems clear the need for the combined action of some HCV proteins. Our results are compatible with those obtained in cell lines expressing the entire HCV ORF where a profound effect on cell oxidative metabolism, depression of mitochondrial membrane potential and increased production of ROS were reported [68]. Functional analysis of human liver biopsies suggest the impairment of key mitochondrial processes, as those described above, during advance stages of fibrosis, evidencing the association between oxidative stress and hepatic mitochondrial dysfunction with HCV pathogenesis [69].

Several in vitro studies revealed that synthesis of HCV structural proteins or the full-length genome have a direct cytotoxic effect or activate an apoptotic response 
$[13,21,70,71]$. Furthermore, the alteration of ER membranes [15] and the activation of signalling pathways characteristic of an ER-stress condition, have been found to be associated with the expression of HCV proteins [7274]. Although these data suggest that HCV may alter intracellular events with possible consequences on liver pathogenesis, the complex mechanism and the role of the viral proteins implicated is under extensive study. Here we showed that HCV polyprotein expression from a VACV recombinant triggered morphological features of apoptosis, such as membrane blebbing and cell shrinkage, that have been described as indicative of cytoskeleton rearrangement due to apoptosis $[75,76]$. Nuclear DNA fragmentation was also observed, as previously examined by others groups using TUNEL staining assay with serum from HCV infected patients [77]. As DNA fragmentation represents a late apoptotic event, we investigated the activation of caspases which are documented to play an important role in the apoptosis detected in various liver disease $[78,79]$. Moreover, the importance of caspases in hepatitis is underscored by studies with pharmacological caspase inhibitors, which potently suppressed experimental hepatitis $[80,81]$.

We found that expression of HCV proteins from the VT7$\mathrm{HCV}_{7.9}$ recombinant increased the activity of initiator and effector caspases and induced apoptosis in a caspasedependent manner; these effects were completely prevented by treatment with specific caspase inhibitors. This activation has been previously observed in cell culture systems individually expressing Core or E2 structural proteins $[71,82]$ and in the HCV RNA replicon when all HCV proteins are produced [13].

The subcellular forms and biochemical effects triggered by $\mathrm{HCV}$ proteins had a profound effect on gene profiling as determined by microarrays. We found up and down regulation in the transcription pattern of several genes associated with lipid metabolism, oxidative stress, apoptosis, mitochondrial dysfunction and cellular proliferation. Since modulation of these genes has been associated with HCV pathogenesis, it suggest that the VAC system expressing the HCV polyprotein impact the host cell somewhat similar as during HCV infection. Thus, the VACV based system is a valuable model in which to investigate critical features of HCV infection and morphogenesis, to characterize virus-host cell interactions and to test the effect of antiviral drugs in the different cell injuries associated with liver diseases.

\section{Methods \\ Cells and viruses}

Cells were maintained in a humidified air $5 \% \mathrm{CO}_{2}$ atmosphere at $37^{\circ} \mathrm{C}$. Human HeLa and monkey BSC40 cells were grown in Dulbecco's modified Eagle's medium
(DMEM) supplemented with 10\% newborn calf serum (NCS). Human HepG2 hepatocellular carcinoma cells (ATCC HB-8065) were maintained in DMEM supplemented with $10 \%$ fetal calf serum (FCS).

The recombinant VT7- $\mathrm{HCV}_{7.9}$, derived from the vaccinia Western Reserve strain (VACV-WR), has been previously described [12]. It contains $7.9 \mathrm{~Kb}$ of the HCV ORF from genotype $1 \mathrm{~b}$ inserted within the viral HA locus under the transcriptional control of the T7 promoter, and expresses the T7 RNA polymerase upon induction with IPTG. The recombinant VV-PKR expressing IPTG-inducible dsRNAdependent protein kinase (PKR) was generated by homologous recombination of their respective pPR35-derived plasmid with the VACV-WR strain as previously described [83]. Viruses were grown and titrated in BSC40 cells and purified by banding on sucrose gradients [84].

\section{Immunofluorescence}

HeLa cells cultured on coverslips were infected at 5 PFU/ cell with VT7- $\mathrm{HCV}_{7.9}$ in the presence or absence of IPTG (1.5 mM final concentration). At $24 \mathrm{~h}$ p.i, cells were washed with PBS, fixed with $4 \%$ paraformaldehyde and permeabilized with $2 \%$ Triton X-100 in PBS (room temperature, $5 \mathrm{~min}$ ). To detect the mitochondria, cells were stained in vivo with Mitotracker Deep Red 633 (Molecular Probes) at $500 \mathrm{nM}$ in DMEM, before fixing the cells. After blockade, cells were incubated for $1 \mathrm{~h}$ at $37^{\circ} \mathrm{C}$ with the specific primary antibodies. The coverslips were then extensively washed with PBS, followed by incubation in the dark for $1 \mathrm{~h}$ at $37^{\circ} \mathrm{C}$ with specific secondary antibodies conjugated with Alexa 488 (green), Alexa 594 (red) or with the green fluorochrome Cy2 (purchased from Molecular Probes), and with the DNA staining reagent ToPro-3 (diluted 1:200). Images were obtained by the Bio-Rad Radiance 2100 confocal laser microscope at a resolution of $63 \mathrm{X}$, collected by Lasersharp 2000 software and processed in LaserPix.

\section{Electron microscopy}

\section{Embedding of infected cells in EML-8 12}

Monolayers of HeLa or HepG2 cells were infected with 5 $\mathrm{PFU} /$ cell of VT7- $\mathrm{HCV}_{7.9}$ in the presence or absence of IPTG. After $16 \mathrm{~h}$, cells were fixed in situ with a mixture of $2 \%$ glutaraldehyde and $1 \%$ tannic acid in $0.4 \mathrm{M}$ HEPES buffer ( $\mathrm{pH} \mathrm{7.2)}$ for $1 \mathrm{~h}$ at room temperature. Fixed monolayers were removed from the culture dishes in the fixative and transferred to Eppendorf tubes. After centrifugation and a wash with HEPES buffer, the cells were stored at $4{ }^{\circ} \mathrm{C}$ until use. For ultrastructure studies, fixed cells were processed for embedding in the epoxy resin EML-812 (TAAB Laboratories, Ltd., Berkshire, UK) as previously described [85]. Postfixation of cells was done with a mixture if $1 \%$ osmium tetroxide and $0.8 \%$ potassium ferricyanide in distilled water for $1 \mathrm{~h}$ at $4{ }^{\circ} \mathrm{C}$. After 
four washes with HEPES buffer, samples were treated with $2 \%$ uranyl acetate, washed again, and dehydrated in increasing concentrations of acetone $(50,70,90$, and $100 \%$ ) for 15 min each time at $4^{\circ} \mathrm{C}$. Infiltration in resin was done at room temperature for 1 day. Polymerization of infiltrated samples was done at $60^{\circ} \mathrm{C}$ for 3 days. Ultrathin sections (40 to $60 \mathrm{~nm}$ thick) of the samples were stained with saturated uranyl acetate and lead citrate by standard procedures. Collections of images were done in a JEOL 1200-EX II electron microscope operating at 100 $\mathrm{kV}$.

\section{Embedding of infected cells in Lowicryl K4M}

Monolayers of HeLa cells were infected with $5 \mathrm{PFU} / \mathrm{cell}$ of VT7- $\mathrm{HCV}_{7.9}$ in the presence or absence of IPTG. After $16 \mathrm{~h}$, cells were fixed in situ with a mixture of $4 \%$ paraformaldehyde and $0.1 \%$ glutaraldehyde in PBS for 30 minutes at $4{ }^{\circ} \mathrm{C}$. Fixed cells were then removed from the dishes and processed for low-temperature embedding in Lowicryl K4M. After extensive washing with PBS, the cells were incubated for 20 minutes with a solution of $0.2 \mathrm{M}$ ammonium chloride, to block any possible free aldehyde groups that may remain in the preparations. Small pellets of chemically fixed cells were cryoprotected with glycerol and quick frozen in liquid propane. Frozen specimens were processed by freeze-substitution for $48 \mathrm{~h}$ at $-90^{\circ} \mathrm{C}$ in a mixture of methanol and $0.5 \%$ (wt $/ \mathrm{vol}$ ) uranyl acetate. Samples were then treated at $-30^{\circ} \mathrm{C}$ with a mixture of Lowicryl K4M:methanol (1:3) for 1 hour, Lowicryl K4M:methanol (1:1) for 1 hour, Lowicryl K4M:methanol (3:1) for 1 hour, followed by an overnight incubation in $100 \%$ Lowicryl. After replacing the resin with a fresh one, samples were kept at $-30^{\circ} \mathrm{C}$ for 8 hours. Finally, the samples were transferred to capsules and polymerized with ultraviolet light for one day at $-30^{\circ} \mathrm{C}$, and two days at room temperature.

\section{Immunogold labeling of ultrathin sections}

Immunogold localization on sections of infected cells was performed by placing the sections on drops of different solutions. After a $30 \mathrm{~min}$ incubation with Tris- $\mathrm{HCl}$ buffer gelatine (TBG) (30 mM Tris-HCl, pH 8.0, containing 150 $\mathrm{mM} \mathrm{NaCl}, 0.1 \% \mathrm{BSA}$, and $1 \%$ gelatin) to block non-specific binding of the antibodies to the samples, sections were floated for $60 \mathrm{~min}$ on a drop of the specific primary antiserum, diluted in TBG. After jet-washing with PBS, grids were floated on 4 drops of TBG and incubated 10 min on the last drop before a 45 min incubation with the secondary antibody, a goat anti-rabbit immunoglobulin $\mathrm{G}$ conjugated with colloidal gold of $10 \mathrm{~nm}$, or goat antimouse IgG+igM conjugated with colloidal gold of 5 or 10 $\mathrm{nm}$ that was purchased from BioCell (Cardiff, UK). Washing was repeated as before, and grids were then floated on several drops of distilled water before staining with a solution of saturated uranyl acetate for $20 \mathrm{~min}$. For double- labelling experiments, representative signals corresponding to both primary antibodies were obtained after testing different combinations of labelling steps.

\section{Imaging and measurements}

Regular thin sections were collected on formvar-coated gold grids of 200 meshes, stained, and studied by EM. Ultrathin sections of the samples were either stained by standard procedures, stained with saturated uranyl acetate in $70 \%$ ethanol (procedure that improves contrast), or processed for immunogold labelling. Collection of images and measurements were done with a JEOL 1200EX II electron microscope operating at $100 \mathrm{kV}$.

\section{Quantification of mitochondrial membrane potential $(\Delta \Psi \mathrm{m})$ and} production of reactive oxygen species (ROS)

Mitochondrial membrane potential was quantified by flow cytometry. Infected and uninfected floating and adhered HeLa cells were collected at $48 \mathrm{~h}$ p.i from the wells, centrifuged at $2500 \mathrm{rpm}$ for $15 \mathrm{~min}$ at $25^{\circ} \mathrm{C}$, washed once with PBS and resuspended in $1 \mathrm{ml}$ of PBS containing $0.2 \mu \mathrm{M}$ TMRE during $30 \mathrm{~min}$ at $37^{\circ} \mathrm{C}$, in the dark. TMRE fluorescence was acquired through the FL-2 channel $(575 \mathrm{~nm})$. Bivariate flow cytometry using a FACScan was performed acquiring 10000 events per sample with fluorescence signals at logarithmic gain analysed with EXPO32 analysis software. The production of reactive oxygen species (ROS) was monitored at $48 \mathrm{~h}$ p.i by staining cells with 2-HE and analysed by FACScan. Cells were treated as indicated above, harvested, and washed with PBS. The pellet was resuspended in MIB buffer [86] and incubated with $2 \mu \mathrm{M}$ of 2 - $\mathrm{HE}$ for $30 \mathrm{~min}$ at $37^{\circ} \mathrm{C}$ in the dark. Analysis was carried out by flow cytometry; 2-HE was measured in FL2 as described above. In both assays staurosporine treated cells were used as positive control.

\section{Measurement of apoptotic cell death}

\section{By cell cycle analysis}

The different stages of cell cycle and the percentage of cells with subG $\mathrm{G}_{0}$ DNA content were analyzed by propidium iodide (PI) staining as previously described [87]. HeLa cells were infected at $5 \mathrm{PFU} / \mathrm{cell}$ with VT7- $\mathrm{HCV}_{7.9}$, in the presence or absence of the inducer IPTG. At $24 \mathrm{~h}$ p.i uninfected and infected cells were removed by pipetting, washed once with cold PBS, and permeabilized with $70 \%$ ethanol in PBS at $4{ }^{\circ} \mathrm{C}$ overnight. After three washes with PBS, the cells were incubated for $45 \mathrm{~min}$ at $37^{\circ} \mathrm{C}$ with RNAse-A $(0.1 \mathrm{mg} / \mathrm{ml})$ and stained with PI $(10 \mu \mathrm{g} / \mathrm{ml})$ during $15 \mathrm{~min}$ at room temperature. The percentage of cells with hypodiploid DNA content was determined by flow cytometry acquiring 15000 events per sample. Cells treated with $0.5 \mu \mathrm{M}$ of staurosporine (Sigma) for $16 \mathrm{~h}$ were used as a positive control of apoptosis induction. 


\section{By ELISA}

HeLa cells were infected as described above in the presence or absence of general and specific caspase inhibitors and harvested at $24 \mathrm{~h}$ p.i. The extent of apoptosis was determined using the cell death detection enzyme-linked immunosorbent assay (ELISA) kit (Roche) according to the manufacturer's instructions. Duplicate samples were measured in two independent experiments. Cells infected with VV-PKR in presence of IPTG were used as positive control. The specific inhibitors of caspase 8 (zIETD-fmk), caspase 9 (zLEHD-fmk) and the general caspases inhibitor (zVAD-fmk) were added to the cells after one hour of virus adsorption at a final concentration of $50 \mu \mathrm{M}$ (Calbiochem).

\section{Analysis by Western blot of active caspases}

To examine expression of active caspases- 8 and 9, HeLa cell monolayers were infected with 5 PFU/cell of VT7$\mathrm{HCV}_{7.9}$, in the presence or absence of the inducer IPTG. Uninfected and infected cells were collected at $48 \mathrm{~h}$ p.i. in lysis buffer (50 mM Tris- $\mathrm{HCl} \mathrm{pH} 8.0,0.5 \mathrm{M} \mathrm{NaCl}, 10 \%$ NP40, 1\% SDS). Equal amounts of protein lysates were separated by $12 \%$ SDS-PAGE, transferred to nitrocellulose membranes and reacted with a primary rabbit antibody against cleaved caspase- 9 or with a primary mouse antibody against cleaved caspase- 8 , followed by the respective secondary antibody. The activation of effector caspases was similarly assayed using a primary rabbit anti-poly(ADP-ribose) polymerase (PARP) antibody, which recognizes the full (116 kDa) and cleaved ( $89 \mathrm{kDa})$ form of PARP.

\section{Microarray analysis}

Total RNA was isolated from HeLa cells infected at 5 PFU/ cell with VT7-HCV ${ }_{7.9}$ in the presence or absence of IPTG at 6 and 16 h p.i with Ultraspect_II RNA (Biotecx, Houston, TX), following manufacturer's instructions. RNA was purified with Megaclear (Ambion, Foster City, CA), and the integrity was confirmed by using an Agilent (Santa Clara, CA) 2100 Bioanalyzer. Two independent replicates were processed for analysis. Total RNA $(1.5 \mu \mathrm{g})$ was amplified with an Amino Allyl MessageAmp aRNA kit (Ambion); 54 to $88 \mu \mathrm{g}$ of amplified RNA (aRNA) was obtained. The mean RNA size was 1,500 nucleotides, as observed using the Agilent 2100 Bioanalyzer. For each sample, $6 \mu \mathrm{g}$ aRNA was labeled with one aliquot of Cy3 or Cy5 Mono NHS Ester (CyDye postlabeling reactive dye pack; GE Healthcare) and purified using Megaclear. Incorporation of Cy5 and Cy 3 was measured using $1 \mu$ l of probe in a Nanodrop spectrophotometer (Nanodrop Technologies). For each hybridization, Cy5 and Cy3 probes (150 mol each) were mixed and dried by speed vacuum and resuspended in 9 $\mu \mathrm{l}$ RNase-free water. Labeled aRNA was fragmented by adding $1 \mu \mathrm{l} 10 \times$ fragmentation buffer (Ambion), followed by incubation $\left(70^{\circ} \mathrm{C}\right.$ for $\left.15 \mathrm{~min}\right)$. The reaction was termi- nated with the addition of $1 \mu \mathrm{l}$ stop solution (Ambion) to the mixture. Two dye-swapped hybridizations were performed for each comparison; in one, the induced-infected sample was Cy3 labeled, and the non-induced-infected sample was Cy5 labeled; in the second, labeling was reversed. Double labeling was used to abolish dye-specific labeling and hybridization differences.

\section{Slide treatment and hybridization}

Slides containing 22,264 spots (21329 different oligonucleotides) corresponding to Human Genome Oligo set version 2.2 (QIAGEN, Hilden, Germany) were obtained from the Genomic and Microarrays Laboratory (Cincinnati University, Cincinnati, OH). Information about printing and the oligonucleotide set can be found on their website http://microarray.uc.edu. Slides were prehybridized and hybridized as described previously [23]. Images from Cy3 and Cy5 channels were equilibrated and captured with an Axon 4000B scanner, and spots were quantified using GenePix 5.1 software. Data for replicates were analyzed using Almazen software (Bioalma, Spain). Briefly, background was subtracted from the signal, Log10 (signal) was plotted versus Log2 (ratio) and Lowess normalization used to adjust most spots to Log Ratio 0. This was calculated for all four replicates and a table was obtained with mean signal, $\mathrm{x}$-fold change, Log Ratio, standard deviation of the Log Ratio, z-score and p-value [88]. Log Ratio and x-fold change were obtained by substracting the non-induced-infected sample gene expression values from those obtained in the induced-infected samples. In each analysis, genes with an interreplicate mean signal of $<50$ or a p-value $>0.1$ were filtered out.

\section{Quantitative real-time RT-PCR}

RNA ( $1 \mu \mathrm{g}$ ) was reverse-transcribed (RT) using the superscript first-strand synthesis system for reverse transcription-PCR (RT-PCR) (Invitrogen). A 1:40 dilution of the RT reaction mixture was used for quantitative PCR. Primers and probe set used to amplify IL-6, H3F3B, and HIST2H4A were purchased from Applied Biosystems. RTPCR reactions were performed according to Assay-onDemand, optimized for TaqMan Universal PCR MasterMix, No AmpErase UNG, as described [22]. All samples were assayed in duplicate. Threshold cycle $(\mathrm{Ct})$ values were used to plot a standard curve in which Ct decreased in linear proportion to the log of the template copy number. The correlation values of standard curves were always > 99\%.

\section{Competing interests}

The authors declare that they have no competing interests.

\section{Authors' contributions}

AMV designed and performed the experiments and drafted the manuscript. CEG designed the study, analyzed 
the data and wrote the paper. CP carried out the electron microscopy studies. EDG performed the experiments. SG carried out the microarrays studies. JMG participated in the analysis of microarray data. ME conceived the study, and participated in its design, coordination and writing. All authors read and approved the final manuscript.

\section{Acknowledgements}

We thank Sylvia Gutierrez for help in confocal microscopy and flow citometry analysis, Carlos Enríquez and Rocío Arranz for electron microscopy support, Luis A. López Fernández for microarray performance, Victoria Jiménez for excellent technical assistance, Dr Illka Julkunen for NS4B and NS5A antibodies and Dr Rafel Fernández for the HCV antibody positive human serum. This investigation was supported by grants from the Spanish Ministry of Education and Science (BIO2002-03246), the EU (QLK2-CT2002-00954) and Fundación Botín.

\section{References}

I. Hoofnagle JH: Course and outcome of hepatitis C. Hepatology 2002, 36:S2I-29.

2. Penin F, Dubuisson J, Rey FA, Moradpour D, Pawlotsky JM: Structural biology of hepatitis C virus. Hepatology 2004, 39:5-19.

3. von Hahn T, Rice CM: Hepatitis C virus entry. J Biol Chem 2008, 283:3689-3693.

4. Lohmann V, Korner F, Koch J, Herian U, Theilmann L, Bartenschlager R: Replication of subgenomic hepatitis C virus RNAs in a hepatoma cell line. Science 1999, 285: I I0-II3.

5. Gosert R, Egger D, Lohmann V, Bartenschlager R, Blum HE, Bienz K Moradpour $D$ : Identification of the hepatitis $C$ virus RNA replication complex in Huh-7 cells harboring subgenomic replicons. J Virol 2003, 77:5487-5492

6. Mizuno M, Yamada G, Tanaka T, Shimotohno K, Takatani M, Tsuji T: Virion-like structures in HeLa G cells transfected with the full-length sequence of the hepatitis $\mathbf{C}$ virus genome. Gastroenterology 1995, 109: 1933-1940.

7. Lindenbach BD, Evans MJ, Syder AJ, Wolk B, Tellinghuisen TL, Liu CC Maruyama T, Hynes RO, Burton DR, McKeating JA, Rice CM: Complete replication of hepatitis $\mathbf{C}$ virus in cell culture. Science 2005, 309:623-626

8. Wakita T, Pietschmann T, Kato T, Date T, Miyamoto M, Zhao Z, Murthy K, Habermann A, Krausslich HG, Mizokami M, Bartenschlager $\mathrm{R}$, Liang TJ: Production of infectious hepatitis $\mathbf{C}$ virus in tissue culture from a cloned viral genome. Nat Med 2005, I I:79|-796.

9. Zhong J, Gastaminza P, Cheng G, Kapadia S, Kato T, Burton DR, Wieland SF, Uprichard SL, Wakita T, Chisari FV: Robust hepatitis C virus infection in vitro. Proc Natl Acad Sci USA 2005, 102:9294-9299.

10. Moss B: Vaccinia virus: a tool for research and vaccine development. Science 1991, 252:1662-1667.

II. Moss B: Genetically engineered poxviruses for recombinant gene expression, vaccination, and safety. Proc Natl Acad Sci USA 1996, 93: II 341-11348.

12. Gomez CE, Vandermeeren AM, Garcia MA, Domingo-Gil E, Esteban $M$ : Involvement of PKR and RNase $L$ in translational control and induction of apoptosis after Hepatitis $C$ polyprotein expression from a vaccinia virus recombinant. Virol J 2005, 2:81.

13. Nomura-Takigawa $Y$, Nagano-Fujii M, Deng L, Kitazawa S, Ishido S, Sada K, Hotta H: Non-structural protein 4A of Hepatitis C virus accumulates on mitochondria and renders the cells prone to undergoing mitochondria-mediated apoptosis. Gen Virol 2006, 87: 1935-1945.

14. Moradpour D, Brass V, Bieck E, Friebe P, Gosert R, Blum HE, Bartenschlager R, Penin F, Lohmann V: Membrane association of the RNA-dependent RNA polymerase is essential for hepatitis C virus RNA replication. J Virol 2004, 78: | 3278-| 3284.

15. Egger D, Wolk B, Gosert R, Bianchi L, Blum HE, Moradpour D, Bienz $\mathrm{K}$ : Expression of hepatitis $C$ virus proteins induces distinct membrane alterations including a candidate viral replication complex. J Virol 2002, 76:5974-5984.
16. Antonsson B: Mitochondria and the Bcl-2 family proteins in apoptosis signaling pathways. Mol Cell Biochem 2004, 256-257: |4|- 155 .

17. Kinnally KW, Antonsson B: A tale of two mitochondrial channels, MAC and PTP, in apoptosis. Apoptosis 2007, 12:857-868.

18. Pahl HL: Signal transduction from the endoplasmic reticulum to the cell nucleus. Physiol Rev 1999, 79:683-70I.

19. Ricci JE, Gottlieb RA, Green DR: Caspase-mediated loss of mitochondrial function and generation of reactive oxygen species during apoptosis. J Cell Biol 2003, 160:65-75.

20. Kalkeri G, Khalap N, Akhter S, Garry RF, Fermin CD, Dash S: Hepatitis $C$ viral proteins affect cell viability and membrane permeability. Exp Mol Pathol 200I, 7 I: 194-208.

21. Kalkeri G, Khalap N, Garry RF, Fermin CD, Dash S: Hepatitis C virus protein expression induces apoptosis in HepG2 cells. Virology 200I, 282:26-37.

22. Guerra S, Lopez-Fernandez LA, Pascual-Montano A, Munoz M, Harshman K, Esteban M: Cellular gene expression survey of vaccinia virus infection of human HeLa cells. J Virol 2003, 77:6493-6506.

23. Guerra S, Najera JL, Gonzalez JM, Lopez-Fernandez LA, Climent N, Gatell JM, Gallart T, Esteban M: Distinct gene expression profiling after infection of immature human monocyte-derived dendritic cells by the attenuated poxvirus vectors MVA and NYVAC. J Virol 2007, $81: 8707-8721$.

24. Piddubnyak V, Rigou P, Michel L, Rain JC, Geneste O, Wolkenstein P, Vidaud D, Hickman JA, Mauviel A, Poyet JL: Positive regulation of apoptosis by HCA66, a new Apaf-I interacting protein, and its putative role in the physiopathology of NFI microdeletion syndrome patients. Cell Death Differ 2007, 14:1222-1233.

25. Su AI, Pezacki JP, Wodicka L, Brideau AD, Supekova L, Thimme R, Wieland S, Bukh J, Purcell RH, Schultz PG, Chisari FV: Genomic analysis of the host response to hepatitis $\mathbf{C}$ virus infection. Proc Natl Acad Sci USA 2002, 99:15669-15674.

26. Castagnetta LA, Agostara B, Montalto G, Polito L, Campisi I, Saetta A Itoh T, Yu B, Chen S, Carruba G: Local estrogen formation by nontumoral, cirrhotic, and malignant human liver tissues and cells. Cancer Res 2003, 63:504I-5045.

27. Tsunedomi $R$, lizuka $N$, Hamamoto $Y$, Uchimura $S$, Miyamoto $T$, Tamesa T, Okada T, Takemoto N, Takashima M, Sakamoto K, Hamada K, Yamada-Okabe H, Oka M: Patterns of expression of cytochrome $\mathbf{P 4 5 0}$ genes in progression of hepatitis $\mathrm{C}$ virusassociated hepatocellular carcinoma. Int J Oncol 2005, 27:66I-667.

28. Martinez C, Garcia-Martin E, Ladero JM, Herraez O, Ortega L, Taxonera C, Suarez A, Diaz-Rubio M, Agundez JA: GSTTI and GSTMI null genotypes may facilitate hepatitis $C$ virus infection becoming chronic. J Infect Dis 2007, 195:1320-1323.

29. Aizaki H, Harada T, Otsuka M, Seki N, Matsuda M, Li YW, Kawakami $\mathrm{H}$, Matsuura Y, Miyamura T, Suzuki T: Expression profiling of liver cell lines expressing entire or parts of hepatitis $\mathbf{C}$ virus open reading frame. Hepatology 2002, 36: |43|-| 438.

30. Rao KN, Elm MS, Kelly RH, Chandar N, Brady EP, Rao B, Shinozuka $\mathrm{H}$, Eagon PK: Hepatic hyperplasia and cancer in rats: metabolic alterations associated with cell growth. Gastroenterology 1997, I I 3:238-248.

31. Cunnea P, Fernandes AP, Capitanio A, Eken S, Spyrou G, Bjornstedt $M$ : Increased expression of specific thioredoxin family proteins; a pilot immunohistochemical study on human hepatocellular carcinoma. Int J Immunopathol Pharmacol 2007, 20:17-24.

32. Teng FY, Tang BL: Cell autonomous function of nogo and reticulons: The emerging story at the endoplasmic reticulum. $J$ Cell Physiol 2008.

33. Bigger CB, Brasky KM, Lanford RE: DNA microarray analysis of chimpanzee liver during acute resolving hepatitis $C$ virus infection. J Virol 200I, 75:7059-7066.

34. Randall G, Panis M, Cooper JD, Tellinghuisen TL, Sukhodolets KE, Pfeffer S, Landthaler M, Landgraf $P$, Kan S, Lindenbach BD, Chien M, Weir DB, Russo JJ, Ju J, Brownstein MJ, Sheridan R, Sander C, Zavolan $M$, Tuschl T, Rice CM: Cellular cofactors affecting hepatitis $C$ virus infection and replication. Proc Natl Acad Sci USA 2007, 104: | 2884-I2889.

35. Chen L, Wang Z, Zhan X, Li DC, Zhu YY, Zhu J: Association of NET-I gene expression with human hepatocellular carcinoma. Int J Surg Pathol 2007, 15:346-353. 
36. Waxman S, Wurmbach E: De-regulation of common housekeeping genes in hepatocellular carcinoma. BMC Genomics 2007, 8:243.

37. Miyoshi A, Kito K, Aramoto T, Abe Y, Kobayashi N, Ueda N: Identification of CGI-I2I, a novel PRPK (p53-related protein kinase)-binding protein. Biochem Biophys Res Commun 2003 303:399-405.

38. Coghlin C, Carpenter B, Dundas SR, Lawrie LC, Telfer C, Murray GI: Characterization and over-expression of chaperonin t-complex proteins in colorectal cancer. J Pathol 2006, 2 I 0:35I-357.

39. Koshida S, Kobayashi D, Moriai R, Tsuji N, Watanabe N: Specific overexpression of OLFM4(GWII2/HGC-I) mRNA in colon, breast and lung cancer tissues detected using quantitative analysis. Cancer Sci 2007, 98:315-320.

40. Nagasaki K, Manabe T, Hanzawa H, Maass N, Tsukada T, Yamaguch $\mathrm{K}$ : Identification of a novel gene, LDOCI, down-regulated in cancer cell lines. Cancer Lett 1999, I 40:227-234.

4I. Bowden MA, Di Nezza-Cossens LA, Jobling T, Salamonsen LA, Nie G: Serine proteases HTRAI and HTRA3 are down-regulated with increasing grades of human endometrial cancer. Gynecol Oncol 2006, I03:253-260.

42. Chung RT, He W, Saquib A, Contreras AM, Xavier RJ, Chawla A, Wang TC, Schmidt EV: Hepatitis C virus replication is directly inhibited by IFN-alpha in a full-length binary expression system. Proc Natl Acad Sci USA 200I, 98:9847-9852.

43. Ikeda M, Yi M, Li K, Lemon SM: Selectable subgenomic and genome-length dicistronic RNAs derived from an infectious molecular clone of the HCV-N strain of hepatitis $\mathbf{C}$ virus replicate efficiently in cultured Huh7 cells. I Virol 2002 76:2997-3006.

44. Kato N, Shimotohno K: Systems to culture hepatitis C virus. Curr Top Microbiol Immunol 2000, 242:26I-278.

45. Myung J, Khalap N, Kalkeri G, Garry R, Dash S: Inducible model to study negative strand RNA synthesis and assembly of hepatitis $\mathbf{C}$ virus from a full-length cDNA clone. J Virol Methods 2001, 94:55-67.

46. Moss B: Poxviridae: the viruses and their replication. In Fields virology 4th edition. Philadelphia: Lippincott/The Williams \& Wilkins Co; 2001:2849-2883.

47. Selby MJ, Choo QL, Berger K, Kuo G, Glazer E, Eckart M, Lee C, Chien D, Kuo C, Houghton M: Expression, identification and subcellular localization of the proteins encoded by the hepatitis C viral genome. J Gen Virol 1993, 74(Pt 6): I I03-III 3.

48. Rouille $Y$, Helle F, Delgrange D, Roingeard P, Voisset C, Blanchard E, Belouzard S, McKeating J, Patel AH, Maertens G, Wakita T, Wychowski C, Dubuisson J: Subcellular localization of hepatitis C virus structural proteins in a cell culture system that efficiently replicates the virus. I Virol 2006, 80:2832-284 I.

49. De Vos R, Verslype C, Depla E, Fevery J, Van Damme B, Desmet V, Roskams $\mathrm{T}$ : Ultrastructural visualization of hepatitis $\mathbf{C}$ virus components in human and primate liver biopsies. I Hepatol 2002, 37:370-379.

50. Falcón V, Acosta-Rivero N, Chinea G, Gavilondo J, de la Rosa M-C, Menéndez I, Dueñas-Carrera S, Viña A, García W, Gra B, Noa M, Reytor E, Barceló MT, Alvarez F, Morales-Grillo J: Ultrastructural evidence of HCV infection in hepatocytes of chronically HCV. infected patients. Biochemical and Biophysical Research Communications 2003, 305:1085-1090.

5I. Pfeifer U, Thomssen R, Legler K, Bottcher U, Gerlich W, Weinmann E, Klinge O: Experimental non-A, non-B hepatitis: four types of cytoplasmic alteration in hepatocytes of infected chimpanzees. Virchows Arch B Cell Pathol Ind Mol Pathol I 980, 33:233-243.

52. Kim JE, Song WK, Chung KM, Back SH, Jang SK: Subcellular localization of hepatitis $\mathbf{C}$ viral proteins in mammalian cells. Arch Virol 1999, 144:329-343.

53. Mottola G, Cardinali G, Ceccacci A, Trozzi C, Bartholomew L, Torris MR, Pedrazzini E, Bonatti S, Migliaccio G: Hepatitis C virus nonstructural proteins are localized in a modified endoplasmic reticulum of cells expressing viral subgenomic replicons. Virology 2002, 293:31-43.

54. Choo Q, Richman KHHJ, Berger K, Lee C, Dong C, Gallegos C, Coit D, Medina-Selby R, Barr PJ, et al:: Genetic organization and diversity of the hepatitis C virus. Proc Natl Acad Sci USA 1991, 88:245I-2455.

55. Takahashi K, Kishimoto S, Yoshizawa H, Okamoto H, Yoshikawa A Mishiro S: p26 protein and 33-nm particle associated with nucleocapsid of hepatitis $\mathbf{C}$ virus recovered from the circulation of infected hosts. Virology 1992, 191:431-434.

56. He LF, Alling D, Popkin T, Shapiro M, Alter HJ, Purcell RH: Determining the size of non-A, non-B hepatitis virus by filtration. J Infect Dis 1987, I 56:636-640.

57. Jacob JR, Burk KH, Eichberg JW, Dreesman GR, Lanford RE: Expression of infectious viral particles by primary chimpanzee hepatocytes isolated during the acute phase of non-A, non-B hepatitis. J Infect Dis 1990, I 6 I: I I2I-I I 27.

58. Lim SP, Soo HM, Tan YH, Brenner S, Horstmann H, MacKenzie JM, $\mathrm{Ng}$ ML, Lim SG, Hong W: Inducible system in human hepatoma cell lines for hepatitis C virus production. Virology 2002, 303:79-99.

59. Huang H, Sun F, Owen DM, Li W, Chen Y, Gale M Jr, Ye J: Hepatitis $C$ virus production by human hepatocytes dependent on assembly and secretion of very low-density lipoproteins. Proc Natl Acad Sci USA 2007, 1 04:5848-5853.

60. Targett-Adams P, Boulant S, McLauchlan J: Visualization of doublestranded RNA in cells supporting hepatitis $C$ virus RNA replication. I Virol 2008, 82:2182-2195.

6I. Gastaminza P, Cheng G, Wieland S, Zhong J, Liao W, Chisari FV: Cellular determinants of hepatitis $C$ virus assembly, maturation, degradation, and secretion. I Virol 2008, 82:2120-2129.

62. Martire G, Viola A, lodice L, Lotti LV, Gradini R, Bonatti S: Hepatitis $C$ virus structural proteins reside in the endoplasmic reticulum as well as in the intermediate compartment/cis-Golgi complex region of stably transfected cells. Virology $200 \mathrm{I}$, 280: $176-182$

63. Serafino A, Valli MB, Andreola F, Crema A, Ravagnan G, Bertolini L, Carloni G: Suggested role of the Golgi apparatus and endoplasmic reticulum for crucial sites of hepatitis $\mathbf{C}$ virus replication in human lymphoblastoid cells infected in vitro. J Med Virol 2003, 70:3I-4I.

64. Barbaro G, Di Lorenzo G, Asti A, Ribersani M, Belloni G, Grisorio B, Filice G, Barbarini G: Hepatocellular mitochondrial alterations in patients with chronic hepatitis $C$ : ultrastructural and biochemical findings. Am / Gastroenterol 1999, 94:21 98-2205.

65. Li Y, Boehning DF, Qian T, Popov VL, Weinman SA: Hepatitis C virus core protein increases mitochondrial ROS production by stimulation of Ca2+ uniporter activity. Faseb 」 2007, 2 I :2474-2485.

66. Wang T, Weinman SA: Causes and consequences of mitochondrial reactive oxygen species generation in hepatitis $\mathbf{C}$. J Gastroenterol Hepatol 2006, 2 I (Suppl 3):S34-37

67. Selimovic D, Hassan M: Inhibition of hepatitis C virus (HCV) core protein- induced cell growth by non-structural protein 4A (NS4A) is mediated by mitochondrial dysregulation. Bosn J Basic Med Sci 2008, 8:4-II.

68. Piccoli C, Scrima R, Quarato G, D'Aprile A, Ripoli M, Lecce L, Boffoli $D$, Moradpour $D$, Capitanio $N$ : Hepatitis $C$ virus protein expression causes calcium-mediated mitochondrial bioenergetic dysfunction and nitro-oxidative stress. Hepatology 2007, 46:58-65

69. Diamond DL, Jacobs JM, Paeper B, Proll SC, Gritsenko MA, Carithers RL Jr, Larson AM, Yeh MM, Camp DG 2nd, Smith RD, Katze MG: Proteomic profiling of human liver biopsies: hepatitis $C$ virus-induced fibrosis and mitochondrial dysfunction. Hepatology 2007, 46:649-657.

70. Sung VM, Shimodaira S, Doughty AL, Picchio GR, Can H, Yen TS, Lindsay KL, Levine AM, Lai MM: Establishment of B-cell lymphoma cell lines persistently infected with hepatitis $C$ virus in vivo and in vitro: the apoptotic effects of virus infection. Virol 2003, 77:2I 34-2I46

7I. Chiou HL, Hsieh YS, Hsieh MR, Chen TY: HCV E2 may induce apoptosis of Huh-7 cells via a mitochondrial-related caspase pathway. Biochem Biophys Res Commun 2006, 345:453-458.

72. Tardif KD, Mori $K$, Siddiqui $A$ : Hepatitis $C$ virus subgenomic replicons induce endoplasmic reticulum stress activating an intracellular signaling pathway. J Virol 2002, 76:7453-7459.

73. Pavio N, Romano PR, Graczyk TM, Feinstone SM, Taylor DR: Protein synthesis and endoplasmic reticulum stress can be modulated by the hepatitis $C$ virus envelope protein E2 through the eukaryotic initiation factor 2alpha kinase PERK. J Virol 2003, 77:3578-3585. 
74. Liberman E, Fong YL, Selby MJ, Choo QL, Cousens L, Houghton M, Yen TS: Activation of the grp78 and grp94 promoters by hepatitis C virus E2 envelope protein. J Virol I999, 73:37। 18-3722.

75. Sebbagh M, Renvoize C, Hamelin J, Riche N, Bertoglio J, Breard J: Caspase-3-mediated cleavage of ROCK I induces MLC phosphorylation and apoptotic membrane blebbing. Nat Cell Biol 200I, 3:346-352.

76. Reed JC: Mechanisms of apoptosis. Am J Pathol 2000, I57:1415-1430.

77. Calabrese F, Pontisso P, Pettenazzo E, Benvegnu L, Vario A, Chemello L, Alberti A, Valente M: Liver cell apoptosis in chronic hepatitis C correlates with histological but not biochemical activity or serum HCV-RNA levels. Hepatology 2000, 3 I : I I53-I I 59.

78. Bantel H, Ruck P, Gregor M, Schulze-Osthoff K: Detection of elevated caspase activation and early apoptosis in liver diseases. Eur J Cell Biol 200I, 80:230-239.

79. Bantel H, Ruck P, Schulze-Osthoff K: In situ monitoring of caspase activation in hepatobiliary diseases. Cell Death Differ 2000, 7:504-505.

80. Kunstle G, Leist M, Uhlig S, Revesz L, Feifel R, MacKenzie A, Wendel $A$ : ICE-protease inhibitors block murine liver injury and apoptosis caused by CD95 or by TNF-alpha. Immunol Lett 1997, 55:5-10.

8I. Rouquet N, Pages JC, Molina T, Briand P, Joulin V: ICE inhibitor YVADcmk is a potent therapeutic agent against in vivo liver apoptosis. Curr Biol 1996, 6: I 192-1 I95.

82. Chou AH, Tsai HF, Wu YY, Hu CY, Hwang LH, Hsu PI, Hsu PN: Hepatitis $\mathrm{C}$ virus core protein modulates TRAIL-mediated apoptosis by enhancing Bid cleavage and activation of mitochondria apoptosis signaling pathway. J Immunol 2005, 174:2160-2166.

83. Lee SB, Esteban M: The interferon-induced double-stranded RNA-activated protein kinase induces apoptosis. Virology 1994, 199:49|-496.

84. Esteban M: Defective vaccinia virus particles in interferontreated infected cells. Virology 1984, 133:220-227.

85. Risco C, Carrascosa JL: Visualization of viral assembly in the infected cell. Histol Histopathol 1999, 14:905-926.

86. Domingo-Gil E, Esteban M: Role of mitochondria in apoptosis induced by the 2-5A system and mechanisms involved. Apoptosis 2006, II:725-738.

87. Martin AG, Fearnhead HO: Apocytochrome c blocks caspase-9 activation and Bax-induced apoptosis. J Biol Chem 2002, 277:50834-5084I.

88. Quackenbush J: Microarray data normalization and transformation. Nat Genet 2002, 32(Suppl):496-50I.

Publish with Biomed Central and every scientist can read your work free of charge

"BioMed Central will be the most significant development for disseminating the results of biomedical research in our lifetime. "

Sir Paul Nurse, Cancer Research UK

Your research papers will be:

- available free of charge to the entire biomedical community

- peer reviewed and published immediately upon acceptance

- cited in PubMed and archived on PubMed Central

- yours - you keep the copyright

Submit your manuscript here:

http://www.biomedcentral.com/info/publishing_adv.asp
BiolMedcentral 